Cornell Law Library

Scholarship@Cornell Law: A Digital Repository

Cornell Law Faculty Publications

Faculty Scholarship

$10-1-2005$

\title{
Applying the Death Penalty to Crimes of Genocide
}

Jens David Ohlin

Cornell Law School, jdo43@cornell.edu

Follow this and additional works at: http://scholarship.law.cornell.edu/facpub

Part of the Human Rights Law Commons, and the International Law Commons

\section{Recommended Citation}

Ohlin, Jens David, "Applying the Death Penalty to Crimes of Genocide" (2005). Cornell Law Faculty Publications. Paper 433.

http://scholarship.law.cornell.edu/facpub/433

This Article is brought to you for free and open access by the Faculty Scholarship at Scholarship@Cornell Law: A Digital Repository. It has been accepted for inclusion in Cornell Law Faculty Publications by an authorized administrator of Scholarship@Cornell Law: A Digital Repository. For more information, please contact jmp8@cornell.edu. 


\title{
APPLYING THE DEATH PENALTY TO CRIMES OF GENOCIDE
}

\author{
By Jens David Ohlin*
}

After the Rwandan genocide of 1994, the United Nations Security Council moved quickly to establish an international tribunal to indict the architects of the slaughter. Whether motivated by a sincere desire for international justice or a self-serving desire to assuage international guilt for the lack of significant military intervention, ${ }^{1}$ one thing is clear: the Security Council began a program that, when coupled with its establishment of the International Criminal Tribunal for the Former Yugoslavia, represented the most significant return to international criminal justice since the Allied prosecution of German war criminals at Nuremberg. ${ }^{2}$ But so much had changed since $1951 .{ }^{3}$ Whereas the Nuremberg Tribunal imposed death sentences for the most culpable instigators of the Holocaust, ${ }^{4}$ there would be no death sentences for the architects of the Hutu genocidal campaign against the Tutsi. Over the course of forty years, there was a sea shift in attitudes about the legality of the death penalty. ${ }^{5}$ When the Allies announced their decision to apply the death penalty at Nuremberg, few objected or suggested that executions would violate international human rights law. ${ }^{6}$ Indeed, Churchill was initially suspicious of the plan for a war crimes tribunal, having assumed that what remained of the Nazi leadership would simply be executed on the battlefield. ${ }^{7}$ As the proceedings unfolded, there were isolated calls for leniency and clemency, and even complaints of victors' justice, but certainly no suggestion that executions violated international law as such. ${ }^{8}$

\footnotetext{
${ }^{*}$ PhD (Philosophy), Columbia University, 2002; JD, Columbia Law School, 2005. I have benefited from conversations with George P. Fletcher and Jonathan Bush.

${ }^{1}$ See UN Doc. S/PV.3453, at 14 (1994) (comments in the Security Council of Rwandan representative Manzi Bakuramutsa, complaining that "the international community, which had troops in Rwanda and could have saved hundreds of thousands of human lives by, for example, establishing humanitarian safe zones, decided instead to withdraw its troops from Rwanda and to abandon the victims to their butchers"); id. at 15 (arguing that "the establishment of so ineffective an international tribunal would only appease the conscience of the international community rather than respond to the expectations of the Rwandese people and of the victims of genocide in particular").

2 See Agreement for the Prosecution and Punishment of the Major War Criminals of the European Axis, Aug. 8, 1945, 59 Stat. 1544, 82 UNTS 279 [hereinafter Prosecution Agreement].

${ }^{3}$ Seegenerally TELFORD TAYLOR, THE ANATOMY OF THE NUREMBERG TRIALS (1992). After the initial round of indictments and prosecutions before the international tribunal in 1945 and 1946, headed by Justice Robert Jackson, the Americans continued a second round of prosecutions under the prosecutorial direction of Taylor until 1951.

${ }^{4}$ Charter of the International Military Tribunal, annex to Prosecution Agreement, supra note 2, Art. 27; see also Control Council Law No. 10, Punishment of Persons Guilty of War Crimes, Crimes Against Peace and Against Humanity, Control Council for Germany, OfFicial GaZeTte, Jan. 31, 1946, at 50, Art. II(3).

${ }^{5}$ See William A. Schabas, The Abolition Of the Death Penalty in InTERnational LaW 2 (3d ed. 2002) ("Fiftyfive years after the Nuremberg trials, the international community has now ruled out the possibility of capital punishment in prosecutions for war crimes and crimes against humanity.").

${ }^{6}$ Those who did object did so on humanitarian and moral grounds, not on the basis of international law. When Uruguay initially objected to the death penalty's use at Nuremberg, it was accused of harboring Nazi sympathies. SCHABAS, supra note 5, at 1 (citing UN Doc. A/C.3/SR.811, para. 28 (1957) (statement of representative of Uruguay)). The philosopher Martin Buber objected to the execution of Adolf Eichmann by the Israelis on religious and political grounds. HANNAH ARENDT, EICHMANN IN JERUSALEM 251 (1963).

${ }^{7}$ PeTer Maguire, LAW AND WAR: AN AMERICAN STORY 90 (2001). Of course, Churchill was eventually persuaded by the intellectual and political advantages of submitting the war crimes question to the rule of law. It would not only provide a public airing of Nazi atrocities, but also highlight the difference between fascist and democratic attitudes about the rule of law. $I d$. at 91 .

${ }^{8}$ On leniency, see, for example, James M. Diehl, U.S. Policy Toward German Veterans, 1945-1950, in AMERICAN POLICY AND THE RECONSTRUCTION OF WEST GERMANY, 1945-1955, at 353, 366 (Jeffry M. Diefendorf, Axel Frohn, \& HeinOnline - $99 \mathrm{Am}$. J. Int'l L. 7472005
} 
But just four decades later when the Security Council authorized the creation of the International Criminal Tribunal for Rwanda (ICTR), few states championed the death penalty. Indeed, many human rights lawyers took for granted that an emerging norm of international law forbade the use of the death penalty in all circumstances, even for the extreme crime of genocide. This view prevailed among the European powers on the Security Council, any one of which could exercise its veto to block empowering a tribunal to impose capital punishment. Just as the permissibility of the death penalty was considered so obvious at Nuremberg that no serious discussion of the matter was required, so its impermissibility was now considered so obvious that once again no serious debate ensued. When the ICTR was finally created, the death penalty was officially off the table. In the span of only four decades, the conventional wisdom among international lawyers had changed dramatically. ${ }^{9}$

But this was certainly not the conventional wisdom among the Rwandan delegation to the United Nations. ${ }^{10}$ The death penalty remains a part of the Rwandan judicial system ${ }^{11}$ and Rwandan diplomats were incensed because the West's failure to prevent the genocide was now being compounded by a judicial system that would allow the perpetrators to escape with their lives. For the Rwandans, true national reconciliation would be possible only if there was justice for the genocide, and justice by their terms meant execution for the guilty. Indeed, prosecutions for genocide in Rwanda's domestic judicial system ended in death sentences, ${ }^{12}$ producing the paradoxical result that the worst offenders-the architects who were tried at the international tribunal-received lighter sentences than those who were convicted by Rwandan courts for mere participation in the genocide. ${ }^{13}$ Although European countries considered Rwanda at fault for this paradox (for engaging in executions in the first place), the

Hermann-Josef Rupieper eds., 1993) (noting the prevailing sentiment that "[t]he officers of the German armed forces ... had not been political and had no decision-making powers").

Despite having been given substantial prison sentences ranging from 10 or 20 years to life sentences, the vast majority of the war criminals were released in the early and mid-1950s after having received executive clemencies. Thomas Alan Schwartz, Die Begnadigung deutscher Kriegsverbrecher: John J. McCloy und die Häflinge von Landsberg, 38 VIERTELJAHRSHEFTE FÜR ZEITGESCHICHTE 375, 406-14 (1990).

On victors' justice, see, for example, Thomas Alan Schwart, John J. McCloy and the Landsberg Cases, in AMERICAN POLICY AND THE RECONSTRUCTION OF WEST GERMANY, supra, at 433, 437 [hereinafter Schwartz, Landsberg Cases] (noting that the clemencies "faithfully reflected popular sentiment in West Germany, where resentment at notions of collective guilt mixed with a form of psychological denial to reduce support for war-crimes trials"). But see THEODOR MERON, From Nurembeng to The Hague, in WAR CRIMES LAW COMES OF AGE 198, 198 (1998) (arguing that the fact "[ $t]$ hat victors sat in judgment did not corrupt the essential fairness of the proceedings").

The idea of capital punishment for war crimes has a long tradition, going back at least as far as Lieber, if not further. U.S. War Department, General Orders No. 100, Apr. 24, 1863, Art. 12 [hereinafter Lieber Code] (providing that "sentences of death shall be executed only with the approval of the chief executive, provided the urgency of the case does not require a speedier execution, and then only with the approval of the chief commander"), Art. 44 (providing for death penalty for rape).

${ }^{9}$ See SCHABAS, supra note 5, at 3 (noting that prohibition of the death penalty will become a universal norm of international law "in the foreseeable future").

${ }^{10}$ UN Doc. S/PV.3453, supra note 1, at 16; see also 1 VIRGINIA MORRIS \& MICHAEL P. SCHARF, THE INTERNATIONAL. CRIMINAL TRIBUNAL FOR RWANDA 71-72 (1998) (describing delays in UN Security Council vote while Rwandan objections were considered).

${ }^{11}$ Although the death penalty was authorized under Rwandan law, the last execution occurred in 1982, and a United Nations report had listed Rwanda among "de facto" abolitionist states after a series of presidential commutations in 1992. Report of the Secretary-General, Capital Punishment and Implementation of the Safeguards Guaranteeing the Protection of the Rights of Those Facing the Death Penalty, UN Doc. E/1995/78; MORRIS \& SCHARF, supra note 10, at 581; see also William A. Schabas, African Perspectives on Abolition of the Death Penalty, in THE INTERNATIONAL SOURCEBOOK ON CAPITAL PUNISHMENT 30, 33 (William A. Schabas ed., 1997) [hereinafter Schabas, African Perspectives].

${ }^{12}$ Indeed, several defendants convicted of genocide in Rwanda were eventually executed. Twenty-two of them were executed in cities across Rwanda on April 24, 1998. Mark A. Drumbl, Rule of Law Amid Lawlessness: Counseling the Accused in Rwanda's Domestic Genocide Trials, 29 ColUM. HUM. RTS. L. REV. 545, 549 n.12 (1998) (noting that thirty thousand spectators crowded into a soccer stadium to witness the public execution of four criminals convicted of genocide); James C. McKinley Jr., As Crowds Vent Their Rage, Rwanda Publicly Executes 22, N.Y. Tmes, Apr. 25, 1998 , at A1.

${ }^{13}$ UN Doc. S/PV.3453, supra note 1, at 16 (Rwandan representative criticizing this disparity). The following sentences have been handed down by the ICTR: Jean-Paul Akayesu, Juvénal Kajelijeli, Jean Kambanda, Jean de Dieu Kamuhanda, Clément Kayishema, Mikaeli Muhimana, Alfred Musema, Ferdinand Nahimana, Emmanuel Ndindabahizi, Hassan Ngeze, Eliezer Niyitegeka, and Georges Rutaganda received life; Emmanuel Bagambiki and André Ntagerura were released; Ignace Bagilishema was acquitted; and Jean Bosco Barayagwiza received 35 years, Sylvestre Gacumbitsi 30 years, Samuel Imanishimwe 27 years, Gérard Ntakirutimana, Obed Ruzindana, and Laurent Semanza 
Rwandans blamed them for imposing their standards of criminal justice on a sovereign nation with distinct cultural norms. Indeed, it was not the West that had suffered the genocide, and it was not the West that must forge a new way of life from the ashes of the genocide.

Part of the disconnect between the Rwandans and the West stemmed from different attitudes about the death penalty and the underlying rationale for criminal punishment. But the rift exposed a deeper trouble with the international jurisprudence of genocide. It is often remarked that the legal prohibition against the death penalty represents an emerging norm of customary international law. ${ }^{14}$ But while there is a growing literature on the death penalty in general, ${ }^{15}$ as well as a sizable literature on the international law of genocide, ${ }^{16}$ the intersection of the two issues has largely been ignored. ${ }^{17}$

The issue is of more than just historical concern. Iraqi government officials have expressed their intention to seek the death penalty against Saddam Hussein for war crimes, crimes against humanity, and genocide. ${ }^{18}$ Indeed, the establishment of an international tribunal to prosecute Hussein was never fully considered because both the U.S. and the Iraqi governments favored keeping the death penalty on the table-an unlikely prospect for an international tribunal. ${ }^{19}$ (Similarly, there was never any serious discussion of an international tribunal for Qaeda terrorists. ${ }^{20}$ ) The abolitionist commitments of many human rights activists and their government supporters have effectively prevented the internationalization of the Iraqi proceedings. But despite the widespread insistence that an emerging norm forbids the imposition of the death penalty, even against Hussein for genocide, these legal arguments are rarely evaluated with dispassionate clarity. If the prohibition is to be applied to cases of genocide as well as cases of regular murder, its applicability must be demonstrated explicitly, not by formalistic reasoning and empty slogans, but by sober legal analysis.

The object of this study is not to determine or question whether customary international law is developing in the direction of a comprehensive prohibition on the death penalty. For purposes of this analysis, it is assumed that there is an emerging norm of customary international law that generally prohibits the death penalty. The question addressed is the content of the norm. Does it or should it apply to genocide?

25 years, Omar Serushago 15 years, Georges Ruggiu 12 years, Elizaphan Ntakirutimana 10 years, and Vincent Rutaganira 6 years. Kajelijeli's life sentence was reduced to 45 years on appeal. See International Criminal Tribunal for Rwanda, ICTR Detainees-Status on 16 August 2005, available at <http://www.ictr.org/ENGLISH/factsheets/ detainee.htm>.

${ }^{14}$ See, e.g., SCHABAS, supra note 5, at 19 (predicting elevation of the prohibition to a customary norm "in the not too distant future").

${ }^{15}$ See, e.g., THE DEATH PENALTY IN AMERICA: CuRRENT ConTroversies (Hugo Adam Bedau ed., 1997); RAYMOND PATERNOSTER, CAPITAL PUNISHMENT IN AMERICA 271 (1991).

${ }^{16}$ See, e.g., MARTHA MiNOW, BETWEen VENGEANCE AND Forgiveness (1998); SteVEn R. RATNER \& Jason S. ABRAMS, ACCOUNTABILITY FOR HUMAN RIGHTS ATROCITIES IN INTERNATIONAL. LAW (2001); GEOFFREY ROBERTSON, CRIMES AGAINST HUMANITY: THE STRUGGLE FOR GLOBAL JUSTICE (2000); THE SPECTER OF GENOCIDE: MASS MURDER in Historical PERSPECTIVe (Robert Gellately \& Ben Kiernan eds., 2003).

${ }^{17}$ Schabas deals with genocide briefly in his comprehensive treatment of the death penalty. SCHABAS, supra note 5, at 241-50. He offers a more complete treatment in War Crimes, Crimes Against Humanity and the Death Penalty, 60 ALB. L. REv. 733 (1997) [hereinafter Schabas, War Crimes]. See also AMNESTY INTERNATIONAL, THE DEATH PENALTY IN WARTIME: ARGUMENTS FOR ABOLITION (AI Index ACT 50/01/94, 1994); LEON SHASKOLSKY SHELEFF, ULTIMATE PENALTIES: CAPITAL PUNISHMENT, LIFE IMPRISONMENT, PHYSICAL TORTURE 198, 217 (1987) (arguing that international law may allow executions for genocide).

${ }^{18}$ See L. Elizabeth Chamblee, Post-War Iraq: Prosecuting Saddam Hussein, 7 CAL. CRIM. L. REV. 1 (2004); Ian Fisher, Face-to-Face and Toe-to-Toe with Iraq's Former Leader, N.Y. TIMES, July 2, 2004, at A1 (noting that the Iraqi government, after the return of sovereignty, overturned the Coalition Provisional Authority's temporary ban on capital punishment).

19 President George W. Bush stated publicly during an ABC News interview that Saddam Hussein should receive the "ultimate penalty" for his crimes. Other U.S. officials, including Sen. Joseph Lieberman, ruled out referring Hussein's case to the International Criminal Court and suggested instead that the United States shop around for a jurisdiction that could impose the death penalty. Richard Cohen, Let Saddam Live, WASH. PoST, Dec. 18, 2003, at A35.

${ }^{20}$ The U.S. government announced its intention to pursue a policy of military tribunals for Qaeda terrorists. Military Order, Detention, Treatment, and Trial of Certain Non-Citizens in the War Against Terrorism, 66 Fed. Reg. 57,833 (Nov. 16, 2001). Although the International Criminal Court could theoretically exercise jurisdiction over Osama bin Laden if he is captured, the ICC would first have to obtain him physically in order to hold a trial. Rome Statute of the International Criminal Court, July 17, 1998, Arts. 12-14, 2187 UNTS 3 [hereinafter Rome Statute].

This is an unlikely prospect. 
Part I will consider what we have termed an emerging norm of customary international law that generally prohibits the death penalty (hereinafter the emerging norm) and how that norm applies in cases of genocide. This analysis is complicated by the fact that international norms are built on the foundation of state practice-and cases of genocide are historically rare. ${ }^{21}$ But the analysis will nonetheless identify strong reasons for excluding genocide from any such emerging norm. Part II will examine why retentionist states might employ the death penalty in cases of genocide and will conclude that these reasons are cognizable under international law and should be factored into any legal analysis of the legality of the death penalty. Part III will explore the dilemma of respecting an alleged human right against execution or respecting a state's legitimate policy reasons for retaining the death penalty to maintain public order. To resolve this dilemma we must recognize that international peace and security is the central goal of international criminal justice, just as it remains a central goal for international law generally. Recognizing the centrality of this norm will provide a framework for addressing the legitimate concerns of states faced with the difficulties of transitional justice.

\section{THE EMERGING ABOLITIONIST NORM IN CUSTOMARY INTERNATIONAL LAW}

Deep disagreement still marks the literature over the permissibility of the death penalty in general. Several scholars have argued that the death penalty violates international legal norms, ${ }^{22}$ while a second camp denies this conclusion and points to the significant number of retentionist states remaining outside the Western Hemisphere. ${ }^{23}$ It is undisputed, of course, that the death penalty was restricted, but not totally prohibited, by the International Covenant on Civil and Political Rights (ICCPR), ${ }^{24}$ although an optional protocol providing for total prohibition has been ratified or acceded to by fifty-four states. ${ }^{25}$ Of course, the list of signatories to the Optional Protocol is dominated by European countries. ${ }^{26}$ The United States, as well as Arab and African countries, reserves the right to retain the death penalty. Furthermore, the Commonwealth countries of the Caribbean region also retain the death

${ }^{21}$ Cf. MiNow, supra note 16, at 1-5 (describing the twentieth century as one "marked by human slaughter and torture").

${ }^{22}$ See SCHABAS, supra note 5, passim (arguing that death penalty violates an internationally recognized right to life); see also Ursula Bentele, Back to an International Perspective on the Death Penalty as a Cruel Punishment: The Example of South Africa, 73 TUL. L. REV. 251, 254 (1998) (arguing that death penalty violates emerging standards of international decency); Joan Fitzpatrick \& Alice Miller, International Standards on the Death Penalty: Shifing Discourse, 19 BROOK. J. INT'L L. 273 (1993); Michelle McKee, Note, Tinkering with the Machinery of Death: Understanding Why the United States' Use of the Death Penalty Violates Customary International Law, 6 BUFF. HuM. RTS. L. REV. 153 (2000); cf. William A. Schabas, Intermational Law and Abolition of the Death Penalty, 55 WASH. \& LEE L. REV. 797, 799 (1998) (admitting that customary international law does not yet prohibit the death penalty but that the goal is near).

${ }^{23}$ See, e.g., RESTATEMENT (THIRD) OF THE FOREIGN RELATIONS LAW OF THE UNITED STATES $\$ 702 \mathrm{cmt} . f(1987)$ [hereinafter RESTATEMENT].

${ }^{24}$ International Covenant on Civil and Political Rights, Dec. 16, 1966, Art. 6(1), 999 UNTS 171 (restricting death penalty to the "most serious crimes"), Art. 6(4) (enshrining right to seek pardon or commutation of a death sentence), Art. 6(5) (prohibiting executions of juveniles and pregnant women), Art. 6(6) (stating that "[n]othing in this article shall be invoked to delay or to prevent the abolition of capital punishment by any State party to the present Covenant") [hereinafter ICCPR].

${ }^{25}$ Second Optional Protocol to the International Covenant on Civil and Political Rights Aiming at the Abolition of the Death Penalty, Dec. 15, 1989, 1642 UNTS 414 [hereinafter Second Optional Protocol] (noting that "all measures of abolition of the death penalty should be considered as progress in the enjoyment of the right to life"). Although 54 states had ratified or acceded to the Optional Protocol as of Sept. 12, 2005, several of them made reservations pursuant to Article 2, which explicitly contemplates reservations for use of the death penalty "in time of war pursuant to a conviction for a most serious crime of a military nature committed during wartime." Spain, Malta, Azerbaijan, Cyprus, and Greece all invoked this article at one time.

${ }^{26}$ As of September 12, 2005, the following states had ratified or acceded to the Second Optional Protocol: Australia, Austria, Azerbaijan, Belgium, Bosnia and Herzegovina, Bulgaria, Cape Verde, Colombia, Costa Rica, Croatia, Cyprus, the Czech Republic, Denmark, Djibouti, Ecuador, Estonia, Finland, Georgia, Germany, Greece, Hungary, Iceland, Ireland, Italy, Liechtenstein, Lithuania, Luxembourg, Malta, Monaco, Mozambique, Namibia, Nepal, the Netherlands, New Zealand, Norway, Panama, Paraguay, Portugal, Romania, San Marino, Serbia and Montenegro, the Seychelles, Slovakia, Slovenia, South Africa, Spain, Sweden, Switzerland, the Former Yugoslav Republic of Macedonia, Timor-Leste, Turkmenistan, the United Kiggdom, Uruguay, and Vẹggzugla 
penalty. ${ }^{27}$ Thus, as a question of treaty-based international law, the death penalty is clearly illegal for those states that have consented to be bound by the Optional Protocol. However, the abolitionists seek a greater prize. Were the prohibition against the death penalty to ripen from treaty-based law into a universal customary norm, even states that refused to sign the Protocol would be subject to the norm. ${ }^{28}$ While the content of the existing treaty-based prohibition and the asserted emerging customary norm may be the same, they are logically distinct sources of law. ${ }^{29}$

Some activists maintain that the treaty prohibition has already hardened into customary law, but scholars take the more moderate position that the norm is still emerging as the number of abolitionist states continues to grow. Assuming, for the purposes of this article, ${ }^{30}$ that a prohibition against the death penalty is slowly ripening into a general norm of customary international law, we ought then to ask discerning questions about the scope of the norm's content. Legal scholars promoting the impending hardening of the treaty norm into customary law often couch the norm in absolute terms. ${ }^{31}$ They maintain that the norm will apply in all cases, even genocide. As argued below, however, a subtle evaluation of the evidence shows that the scope of the emerging norm will be far less categorical. ${ }^{32}$

In the next section, we evaluate the objective element of state practice by looking at two areas: the international agreements that prohibit the death penalty, and actual prosecutions for genocide in domestic and international fora. We then evaluate the subjective element of opinio juris by considering the negotiating history behind the international agreements. ${ }^{33}$ This evidence will be interpreted in conjunction with an analysis of the abolitionist movements that have significantly influenced the emerging norm.

\section{State Practice}

Any analysis of customary international law must begin with state practice. ${ }^{34}$ Our examination of state practice reveals that large-scale crimes such as genocide and crimes against

${ }^{27}$ The list of Caribbean retentionist states includes Antigua and Barbuda, the Bahamas, Barbados, Belize, Dominica, Grenada, Guyana, Jamaica, St. Christopher and Nevis, St. Lucia, St. Vincent and the Grenadines, and Trinidad and Tobago. See Julian B. Knowles, Capital Punishment in the Commonwealth Caribbean: Colonial Inheritance, Colonial Remedy? in CAPITAL PUNISHMENT: STRATEGIES FOR ABOLITION 282, 282 (Peter Hodkinson \& William A. Schabas eds., 2004). Although several of the Caribbean countries have repealed mandatory capital punishment for capital offenses, there appears to be little movement toward total abolition. See id. at 284-85.

${ }^{28}$ This conclusion is subject, of course, to issues of persistent objector status. However, even persistent objector status would be insufficient to relieve the retentionist states of their obligation if the prohibition were not only customary, but also peremptory and nonderogable, i.e., jus cogens.

${ }^{29}$ See Military and Paramilitary Activities in and Against Nicaragua (Nicar. v. U.S.), 1986 ICJ REP. 14, 96, para. 179 ( June 27).

${ }^{90}$ We will not directly tackle the question of the death penalty's general permissibility under international law, because it need not be answered to settle the question at hand. A reader who denies the existence of the legal norm altogether will have no difficulty agreeing that the death penalty could be applied to crimes of genocide. It is only those lawyers who believe that the international legal norm does exist who must be convinced that crimes of genocide fall outside the scope of the norm.

${ }^{31}$ See SCHABAS, supra note 5 , at 19.

${ }^{32}$ This type of analysis is surprisingly absent from the current literature. Perhaps there are two reasons. Those scholars who champion abolition as a future customary norm are inclined to view it as absolute, and so are disinclined to inquire whether it will apply in cases of genocide. On the other hand, scholars who question the existence of a customary norm have no reason to analyze its scope because they deny its existence tout court. Consequently, the question remains underexplored. One exception is SHELEFF, supra note 17, at 216-17 (arguing that the death penalty may be justified for genocide and that the issue is an open one under international law).

${ }^{33}$ See International Law Association, Committee on Formation of Customary (General) International Law, Statement of Principles Applicable to the Formation of General Customary International Law, at 31 (2000) [hereinafter ILA, Customary International Law] (noting that the subjective element is not necessary for establishing a customary norm, although it would be a sufficient condition). H. W. A. THIRLWAY, INTERNATIONAL CUSTOMARY LAW AND CODIFICATION 47 (1972), takes note of the disagreement among scholars on the necessity of showing opinio juris:

The precise definition of the opinio juris, the psychological element in the formation of custom, the philosophers' stone which transmutes the inert mass of accumulated usage into the gold of binding legal rules, has probably caused more academic controversy than all the actual contested claims made by States on the basis of alleged custom, put together.

${ }^{34}$ See MAARTEN BOS, A MĖTHODOLOGY OF INTERNATIONAL LAW 234 (1984) (noting that practice must achieve "virtual uniformity"); LOUIS HENkIN, INTERNATIONAL LAW: POLITICS AND VALUES 29 (1995) (noting that customary law is easy to define but difficult to apply). Henkin responds to these difficulties by dividing customary international HeinOnline -- $99 \mathrm{Am}$. J. Int'l L. 7512005 
humanity are often treated differently. States have rarely forgone the death penalty after genocide. ${ }^{35}$ Moreover, too few domestic prosecutions for genocide have occurred to establish the emerging legal norm, ${ }^{36}$ and the international prosecutions are of little use. ${ }^{37}$ Finally, our examination shows that executions for genocide did not give birth to the international abolitionist movement; displeasure over executions for domestic offenses played a larger role in the development of the movement ${ }^{38}$ Consequently, the evidence does not suffice to establish either the objective or the subjective element of a general rule of customary international law prohibiting the death penalty in cases of genocide.

The first aspect of state practice to consider in the case of the death penalty is the international agreements that prohibit capital punishment. ${ }^{39}$ Although treaties are not evidence of a customary norm per se, ${ }^{40}$ their ratification by individual states may constitute evidence of state practice. ${ }^{41}$ This effect can certainly be attributed to the agreements that seek abolition of the death penalty. The second aspect of state practice is actual prosecutions for genocide, because they provide a window into how states have actually responded to that crime. This kind of state practice is the most powerful because it is the least susceptible to ambiguity. But as the following analysis demonstrates, neither of these two categories is sufficient to demonstrate a uniform state practice to abolish the death penalty for crimes of genocide.

All too often, analysis of state practice relies on verbal pronouncements and treaty terms, at the expense of actual conduct. Although the international commitments of each state must be traced, whether through codified treaty terms or more informal verbal statements, it is nonetheless regrettable that mere verbal pronouncements, unsupported by actual conduct, are regarded as sufficient to establish a norm of customary international law. There are good reasons to be suspicious of promises that do not blossom into full-fledged conduct. Either the alleged rule is an empty piety because it is too general or, worse still, the statements are disingenuous. Consequently, as the following analysis demonstrates, our evaluation of a customary rule against the death penalty must temper its reliance on treaty terms with respectful consideration of actual prosecutions for genocide.

The Charters, the Covenant, and the Second Optional Protocol. International instruments that prohibit the death penalty often make explicit exceptions for grave offenses. For example,

law into four distinct categories: constitutional law, basic law, established customary law, and contemporary customary law. Id. at 31 . A customary prohibition against the death penalty would fall into the final category, because it represents a recent attempt to "generate" new international law and bind states that refuse to adopt the Optional Protocol. $I d$. at 37. This method of generating new law is "perhaps functionally satisfactory if not conceptually pure." Id. at 38. See also North Sea Continental Shelf Cases (FRG/Den.; FRG/Neth.), 1969 ICJ REP. 3, 41 (Feb. 20).

${ }^{35}$ See infra notes 63-67 and corresponding text.

${ }^{36}$ The number of states that have prosecuted crimes of genocide is small, and the number that have done so without the death penalty is even smaller. See text at notes 63-64 infra.

${ }^{37}$ International prosecutions, insofar as they are international, do not fall within the confines of state practice. See infra notes 60-62 and corresponding text.

38 See infra notes 100-09 and corresponding text.

${ }^{39}$ See OSCAR SCHACHTER, INTERNATIONAL LAW IN THEORY AND PRACTICE 338 (1991) (arguing that the traditional evidence of state practice and opinio juris is absent in the case of human rights norms, so recourse must be made "mainly" to "international forums where human rights issues are actually discussed, debated and sometimes resolved by general consensus"). Schachter lists the traditional evidence for a customary norm as claims by states against each other. Id. at 336. Since states rarely file official diplomatic protests against another state's treatment of its own citizens, establishing human rights norms as customary norms may require broadening the inquiry to include "pronouncements by national leaders, legislative enactments, judicial opinions, and scholarly studies." Id. at 338.

${ }^{40}$ RESTATEMENT, supra note $23, \$ 102, \mathrm{cmt}$. $i$ (arguing that international agreements are distinct from customary law but may be evidence of state practice when states sign them out of legal obligation). International agreements may also codify customary law, id., although there is no evidence that the international agreements prohibiting the death penalty were codifying preexisting custom. One might argue that they codified existing custom among the agreeing states. If so, however, the result would be particular customary law, not general customary law.

${ }^{41}$ For an action to count as state practice, it must be performed by a competent organ of the state. Bos, supra note 34, at 234 (noting that this requirement includes organs "designated by a State's constitution," and possibly "customary rules created by the practice of low-ranking officials"). 
Article 6(2) of the ICCPR declares that "[i]n countries which have not abolished the death penalty, sentence of death may be imposed only for the most serious crimes." ${ }^{22}$ Furthermore, the UN Human Rights Committee has recognized that state parties "are not obliged to abolish the death penalty totally" but only "for other than the "most serious crimes." 43 Likewise, both the American Convention on Human Rights and the Arab Charter of Human Rights specifically recognize the death penalty for severe crimes. ${ }^{44}$ Protocol No. 6 to the European Convention on Human Rights and Fundamental Freedoms (ECHR), while contemplating abolition, nonetheless allows states to retain the death penalty for crimes committed during times of war or an imminent threat of war. ${ }^{45}$ Several national courts have held that capital punishment may be justified in extreme situations, or at the very least that the practice cannot be condemned in those situations. ${ }^{46}$ Some nations have amended their constitutions to exclude the death penalty except for heinous crimes, ${ }^{47}$ while others have passed statutes limiting it to crimes committed during wartime and those of an extreme nature. ${ }^{48}$ These examples suggest that the legality of the death penalty under treaty law is informed, at least in part, by the seriousness of the offense to which it is applied. ${ }^{49}$ Since the customary norm is alleged to be emerging from the treaty-based prohibition, the exception for serious crimes will probably be carried forward into the customary norm. Thus, even if one day the treaty obligations prohibiting the death penalty established a norm of prohibition under customary international law, it would be incorrect to say that the norm applied in all cases. If the customary norm is to be broader and more extensive than the treaty-based norm, it must be defended solely on the basis of state practice and opinio juris, apart from and in addition to the treatybased norm.

One major convention does include a blanket prohibition against the death penalty, even in cases of war crimes and genocide..$^{50}$ Protocol No. 13 to the European Convention on

42 ICCPR, supra note 24, Art. 6(2).

${ }^{43}$ Human Rights Committee, General Comment No. 6, The Right to Life, UN Doc. HRI/GEN/1, at 5, para. 6 (1982).

${ }^{44}$ American Convention on Human Rights, Nov. 22, 1969, Art. 4(2), OAS TS No. 36, 1144 UNTS 123 (entered into force July 18, 1978). The United States has not ratified the American Convention. Twenty-five countries have ratified the Convention, which was followed by the Protocol to the American Convention on Human Rights to Abolish the Death Penalty, June 8, 1990, OAS TS No. 73, 29 ILM 1447 (1990) [hereinafter American Protocol]. However, even this Protocol anticipates that some states might reserve the right to use the death penalty for serious war crimes. Id., Art. 2(1).

Arab Charter on Human Rights, Sept. 15, 1994, Art. 10, 18 HUM. RTS. L.J. 151 (1997), available at <http:// wwwl.umn.edu/humanrights $>$. The Charter has not entered into force because only one state has ratified it.

${ }^{45}$ Protocol No. 6 to the European Convention for the Protection of Human Rights and Fundamental Freedoms Concerning the Abolition of the Death Penalty, Apr. 28, 1983, Arts. 1, 2, Europ. TS No. 114 (entered into force Mar. 1, 1985). For the Convention, Nov. 4, 1950, see Europ. TS No. 5, 213 UNTS 221 [hereinafter ECHR].

${ }^{46}$ See, e.g., Kaunda v. President, 2004 (10) BCLR 1009, para. 98 (CC) (S. Afr.), reprinted in 44 ILM 173 (2005) (stating that capital punishment "is still not impermissible under international law" (Chaskalson, CJ)); State v. Makwanyane, 1995 (6) BCLR 665, paras. 36, 94 (CC) (S. Afr.), 1995 SACLR LEXIS 218 (noting that "capital punishment is not prohibited by public international law" and that "proportionality is an ingredient to be taken into account" and "many countries ... still retain the death penalty as a sentencing option for such cases [murder]" (Chaskalson, J.)); see also United States v. Burns, 1 S.C.R. 283 (2001) (holding that extradition from Canada to a state where the death penalty might be imposed is unconstitutional save for exceptional cases), discussed in William A. Schabas, Indirect Abolition: Capital Punishment's Role in Extradition Law and Practice, 25 LOY. L.A. INT'L \& COMP. L. REV. 581,599 (2003).

47 See, e.g., CONST. Art. III, sec. 19 (Phil.), discussed in Ariane M. Schreiber, Note, States That Kill: Discretion and the Death Penalty-A Worldwide Perspective, 29 CORNELL INT'L L.J. 263, 272-73 (1996).

48 These states included, as of May 24, 2005, Albania, Argentina, Bolivia, Brazil, Chile, the Cook Islands, El Salvador, Fiji, Israel, Latvia, and Peru. Amnesty International, Abolitionist and Retentionist Countries, at $<$ http:// web.amnesty.org/pages/deathpenalty-countries-eng >.

${ }^{49}$ See Christy A. Short, Note, The Abolition of the Death Penalty: Does "Abolition" Really Mean What You Think It Means? 6 IND. J. GLOBAL LEGAL STUD. 721, 750-51 (1999) (arguing that the death penalty does not violate customary international law because, inter alia, many states have abolished it for ordinary crimes but still reserve the right to use it in extreme cases or wartime).

${ }^{50}$ Protocol No. 13 to the Convention for the Protection of Human Rights and Fundamental Freedoms, Concerning the Abolition of the Death Penalty in All Circumstances, opened for signature May 3, 2002, Europ. TS No. 187, 41 ILM 515 (2002) (entered into force Jan. 7, 2003)

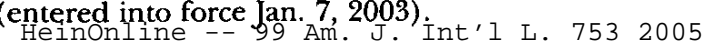


Human Rights has been acceded to or ratified by forty-four states and extends the prohibitions of Protocol No. 6 to all circumstances. ${ }^{51}$ Although Protocol No. 13 is convincing evidence that most of Europe is moving in the direction of absolute abolitionism, it is nonetheless a profoundly European development. Indeed, becoming a party to Protocol No. 13 and the other optional protocols to the ECHR is widely considered to be a necessary step toward entry into the European Union. Until Protocol No. 13, or an analogous commitment, gains substantial support from other continents, particularly those dealing with the specter of genocide, its legal prohibitions will be insufficiently widespread to spawn a corresponding customary norm binding on all states. ${ }^{52}$

International prosecutions for genocide. If the abolitionist norm is to apply even in cases of genocide, there ought to be state practice in the form of prosecutions where an obligation under international law prohibited the death sentence. Unfortunately, the record indicates that prosecutions for genocide- both domestic and international-are few and far between. This lacuna in state practice frustrates the formation of the customary international law norm. ${ }^{53}$ At the least, it should call the content of the norm into question.

The first point is obvious: the number of relevant precedents is limited by the number of times the crime has been committed. It has been suggested that there were only three real genocides in the twentieth century (as opposed to lesser genocidal crimes).$^{54}$ If that assumption is correct, then the relevant precedents in terms of actual prosecutions include the Nuremberg trials, and the proceedings in the ICTY and the ICTR. This practice hardly constitutes overwhelming precedent for a rule of customary international law, especially when one considers that the death penalty was applied at Nuremberg. And while the ICTY, the ICTR, and the Special Court for Sierra Leone may not apply the death penalty, this prohibition is partly political in nature ${ }^{55}$ For example, the Sierra Leone tribunal was set up by a negotiated agreement between the UN secretary-general and Sierra Leone.$^{56}$ But it is funded by the voluntary payments of member states. ${ }^{57}$ If the death penalty were not prohibited at the Special Court, it would be next to impossible to secure funding from European and certain other major donors. ${ }^{58}$ Hence, one must proceed carefully before assuming a broad consensus on the proposition that international law required removal of the death penalty option from the Special Court's Statute. It is equally plausible that key states would not move the process forward unless the death penalty was off the table, and reluctant states acceded

\footnotetext{
${ }^{51}$ These states included as of September 13, 2005, Albania, Andorra, Armenia, Austria, Azerbaijan, Belgium, Bosnia and Herzegovina, Bulgaria, Croatia, Cyprus, the Czech Republic, Denmark, Estonia, Finland, France, Georgia, Germany, Greece, Hungary, Iceland, Ireland, Italy, Latvia, Liechtenstein, Lithuania, Luxembourg, Malta, Moldova, the Netherlands, Norway, Poland, Portugal, Romania, San Marino, Serbia and Montenegro, Slovakia, Slovenia, Spain, Sweden, Switzerland, the Former Yugoslav Republic of Macedonia, Turkey, Ukraine, and the United Kingdom.

${ }^{52}$ See infra notes 67-68 and corresponding text for a discussion of the doctrine of "specially affected" states.

${ }^{53}$ José E. Alvarez, Crimes of States/Crimes of Hate: Lessons from Rwanda, 24 YALE J. INT'L L. 365, 408 n.215 (1999).

${ }^{54}$ See id. (citing Alain DesteXhe, Rwanda AND Genocide IN THE TwENTIETH Century 21-35 (1995) (arguing that the Holocaust, Rwanda, and Yugoslavia represent the only three cases of full genocide during the century)). On the Rwandan genocide, see generally PHILIP GOUREVITCH, WE WISH TO INFORM YOU THAT TOMORROW WE WILL BE KILlED WITH OUR FAMILIES (1998); CHRISTOPHER C. TAYlor, SACRIFICE AS TERror: THE RWANDAN GeNOCIDE OF 1994 (1999).

${ }^{55}$ On the ICTY and ICTR, see, for example, text at notes 92-99 infra.

${ }^{56}$ Act No. 9, Special Court Agreement, reprinted in 133 Sierra Leone Gazette, No. 22, Apr. 25, 2002, Supp. at 2. On the Special Court's development, see Elizabeth M. Evenson, Note, Truth and Justice in Sierra Leone: Coordination Between Commission and Court, 104 CoLUM. L. REv. 730, 738 (2004).

${ }^{57}$ Stephanie H. Bald, Note, Searching for a Lost Childhood: Will the Special Court of Sierra Leone Find Justice for Its Children? 18 AM. U. INT'L L. REV. 537, 560 (2002).

${ }^{58} \mathrm{Id}$. at 569-70 (noting that the funding structure was the "only politically viable option"); id. at 571 (noting that "[b]y allowing other states to make voluntary contributions, the Special Court's independence may be jeopardized by significant contributions from donor states"); see also Agreement on the Establishment of a Special Court for

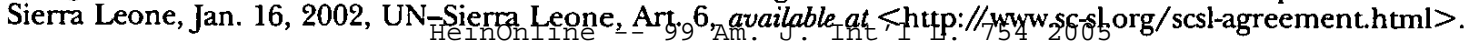


to this demand for reasons of expediency rather than principle. ${ }^{59}$ In sum, the Special Court's death penalty prohibition has little value in terms of establishing the customary norm.

But there is a more fundamental objection to using the international tribunals as evidence of state practice. Although the international tribunals are staffed by prosecutors and judges from member states, as institutions they function at the international level. Since they make determinations collectively-not individually as state agents-their decisions cannot be regarded as evidence of state practice. ${ }^{60}$ While their very existence is authorized by individual states, either tacitly through participation or explicitly in the case of the Security Council members that voted for their creation, this is a logically distinct point. That is, one might evaluate the original authorization as a form of state practice, ${ }^{61}$ but it would be wrong to count the decisions of the tribunal as state practice. Consequently, the fact that the ICTY and the ICTR have handed down prison terms for genocide convictions-in lieu of death sentences-is not relevant to our analysis of the emerging norm. ${ }^{62}$ Its only relevance is to establish the subjective understanding of those members of the Security Council that voted to establish the tribunals.

Domestic prosecutions for genocide. Although prosecution for genocide is now usually an international affair, isolated domestic cases have been pursued. Yet if we widen the scope of our analysis to include domestic prosecutions, there is still not enough evidence to support a customary prohibition. The list would include Rwanda, Yugoslavia, Israel, Switzerland, and, in the near future, Iraq. ${ }^{63}$ In most of these cases the prosecutions either concluded with death sentences or the death penalty was available as an option. ${ }^{64}$ There are sound jurisprudential reasons for giving these prosecutions a prominent place in our analysis. A customary norm can be established only if it is practiced by an extensive ${ }^{65}$ and representative ${ }^{66}$ number of states. Representative state practice includes those states that are "specially affected" by the norm in question. ${ }^{67}$ The specially affected states notably include those that have faced the task of rebuilding societies and communities in the wake of genocide. Actual prosecutions

\footnotetext{
59 Indeed, Sierra Leone retains the death penalty under its domestic law, producing the same paradoxical result as in Rwanda, where the worst offenders are eligible for lower punishments because they are tried at the international tribunal. Bruce M. Mackay, A View from the Trenches: The Special Court for Sierra Leone-The First Year, 35 CASE W. RES. J. INT'L L. 273, 279 (2003).

${ }^{60}$ See ILA, Customary International Law, supra note 33, at 18 ("Although international courts and tribunals ultimately derive their authority from States, it is not appropriate to regard their decisions as a form of State practice.").

${ }^{61}$ See infra notes 90-93 and corresponding text.

62 This is not to say, of course, that the decisions of the ad hoc tribunals are not relevant precedents for international criminal law. In handing down their decisions, the tribunals interpret major elements of international criminal law, and these interpretations are persuasive authority that guides future interpreters of international law. But the precedential value of these decisions ought to be kept separate from their value as indicators of state practice for the purposes of customary international law.

${ }^{63}$ On Rwanda, see infra notes 122-36 and corresponding text.

In 1946 the Yugoslavs prosecuted Draža Milhailović and others for genocide. Several defendants were sentenced to death and executed. In 1986 the Yugoslavs sentenced Andrija Artukovic to death, although he died in prison before the sentence could be carried out. Schabas, War Crimes, supra note 17, at 762.

On Israel, see ARENDT, supra note 6, passim (discussing Eichmann's prosecution and eventual execution for genocide).

On Switzerland, see Niyonteze v. Public Prosecutor (Trib. militaire de cassation, Apr. 27, 2001), available at $<$ http://www.vbs.admin.ch/internet/OA/d/urteile.htm>. A Swiss court exercised universal jurisdiction in hearing a case against a former mayor accused of ordering the massacre of Tutsi and moderate Hutu in his village. He was convicted and sentenced to life in prison, although an appellate court subsequently reduced the sentence to fourteen years. See generally Luc Reydams, Case Report: Niyonteze v. Public Prosecutor, in 96 AJIL 231 (2002).

On Iraq, see text at notes $139-40$.

${ }^{64}$ The exception was Switzerland. Canada, an abolitionist state, recently charged Desire Munyaneza with genocide in connection with attacks against Tutsi at the National University of Rwanda.

${ }^{65}$ See Bos, supra note 34 , at 231 (discussing the condition that a sufficient number of states must engage in the state practice for the norm to become customary law); THIRLWAY, supra note 33, at 100. See generally ANTHONY D'AMATO, THE CONCEPT OF CUSTOM IN INTERNATIONAL LAW (1971).

${ }^{66}$ See BOS, supra note 34, at 233 (citing the ICJ's North Sea Continental Shelf Cases (FRG/Den.; FRG/Neth.), 1969 ICJ REP. 3, 41 (Feb. 20)); THIRLWAY, supra note 33, at 100.

${ }^{67}$ North Sea Continental Shelf Cases, 1969 ICJ REP at 43, see also BgS, sytra note 34, at 233.
} 
for genocide by these states in particular have greater norm-creating value than merely formal prohibitions against the death penalty in states that have never faced genocide. ${ }^{68}$

To establish that the customary norm applies to genocide, the doctrine of specially affected states requires evidence that states victimized by genocide have refrained from imposing the death penalty as part of a perceived duty under international law. But the opposite is the case ${ }^{69}$ In the majority of full-scale genocides during the last century, the death penalty was available for domestic prosecutions.

Discrepant practice. Isolated instances of noncompliance are insufficient to disprove the existence of a customary norm. We must ask, however, to what degree the instances are actually isolated. If we consider death penalty prohibitions simpliciter, then the cases of death sentences for genocide are few and exceptional. But we must choose the relevant background carefully. The relevant background is actual cases of genocide and how specially affected states have dealt with them. While some Security Council members were certainly unwilling to vote for the ad hoc tribunals unless capital punishment was not an option, it is also true that Rwanda executed perpetrators of the genocide $;^{70}$ several countries retain the right to impose the death penalty for genocide and war crimes; ${ }^{71}$ and the upcoming Iraqi tribunal will be authorized to impose capital punishment for grave crimes. ${ }^{72}$ Finally, the World War II tribunals, still the most valuable precedent in the law of genocide, imposed the death penalty. These counterexamples may not be definitive, but they complicate the situation enough to open to question whether the death penalty violates international law in all circumstances. ${ }^{73}$ At the least, the evidence is sufficient to force reconsideration of the legal issues. For some countries, the gravity of the crime makes a difference, and this fact ought to be recognized in the formation of a more nuanced norm of customary international law.

\section{The Subjective Element: Opinio Juris}

Some commentators have argued that opinio juris is sufficient to establish a customary norm even in the face of insufficient practice. ${ }^{74}$ Be that as it may, the evidence is far too ambiguous ${ }^{75}$ to support the subjective element of the norm, either independently or in conjunction with state practice.

The Rome Statute. The negotiating history of the Rome Statute of the International Criminal Court (ICC) could be powerful evidence for the proposition that international law prohibits the death penalty even for cases of genocide. ${ }^{76}$ After all, the ICC was designed for the prosecution of the most serious crimes, ${ }^{77}$ including genocide. ${ }^{78}$ But a nuanced evaluation of the historical evidence paints a more complicated picture.

${ }^{68}$ ILA, Customary International Law, supra note 33, at 26 . What matters most for state practice in our analysis is how states faced with genocide have responded, not how states claim they might respond in a hypothetical example.

${ }^{69}$ See Alvarez, supra note 53, at $408 \mathrm{n} .215$ (pointing out that in no case "has the international community required a nation [to forgo the death penalty] by binding Security Council order, and those nations that have chosen a more merciful route have therefore done so based on their own calculation of what would work best for national reconciliation").

${ }^{70}$ See supra note 12 and corresponding text.

${ }^{71}$ See Tung Yin, Disposable Deontology: The Death Penalty and Nuclear Deterrence, 55 ALA. L. REv. 111, 111-12 (2003) (discussing scenarios where bin Laden is captured and is subject to capital punishment by the U.S. government).

72 See supra note 18 and corresponding text.

${ }^{79}$ Compare SCHABAS, supra note 5, passim, with Alvarez, supra note 53, at 408 n.215.

${ }^{74}$ In other words, a relative lack of state practice may be compensated for by a robust showing of the subjective element. ILA, Customary International Law, supra note 33, at 40.

${ }^{75} \mathrm{Id}$. at 36 ("Some conduct is too ambiguous to be treated, without more, as constituting a precedent capable of contributing to the formation of a customary rule. In such cases, the conduct will only count if there is positive evidence that the State or States concerned intended, understood or accepted that a customary rule could result from, or lay behind, the conduct in question.").

${ }^{76}$ For a general discussion of sentencing at the ICC, see Daniel B. Pickard, Proposed Sentencing Guidelines for the International Criminal Court, 20 LOY. L.A. INT'L \& COMP. L.J. 123 (1997).

${ }^{77}$ Rome Statute, supra note 20 , pmbl. (recognizing that "millions of children, women and men have been victims of unimaginable atrocities that deeply shock the conscience of humanity" and proclaiming that "the most serious crimes of concern to the international community as a whole must not go unpunished").

${ }^{78}$ Id., Art. 6 (defining genocide as the intent to destroy, in whole or in part, a national, ethnic, racial, or religious group by killing, causing serious bodily or mental harm, deliberately inflicting conditions calculated to bring about physical destruction, imposing measures to prevent births, and transferring children to another group). 
When the International Law Commission began drafting the code for a future international criminal court in 1991, the negotiations bogged down over the issue of capital punishment. The majority of the countries involved in the negotiations wanted to exclude the death penalty explicitly from the future court's purview. ${ }^{79}$ A smaller-but vocal-group wanted to include the death penalty. ${ }^{80} \mathrm{~A}$ practical compromise was forged that eventually led to the exclusion of the death penalty from the Rome Statute. ${ }^{81}$ A key element of the compromise was the explicit condition that the decision not be understood as having been based on a sense of legal duty and that the compromise should in no way contribute to the formation of a customary norm prohibiting the death penalty ${ }^{82}$ Furthermore, several retentionist countries supported the compromise because they concluded that it would not inhibit national jurisdictions from applying the death penalty when exercising their primary jurisdiction over criminal matters. ${ }^{83}$

The United States was willing to support the compromise, ${ }^{84}$ even though it continues to impose the death penalty and maintains its legality under international law. The United States suggested excluding the death penalty from the tribunal's menu of punishments on the basis of political and diplomatic calculations; ${ }^{85}$ many countries would be unwilling to accept the Rome Statute if the death penalty were included as a potential punishment. ${ }^{86}$ 79 Representatives from Japan, Kenya, Algeria-even the U.S. representative-all spoke out in favor of excluding
the death penalty. Schabas, War Crimes, supra note 17, at 748-49. These representatives to the International Law
Commission expressed a view held by other countries not represented in that particular forum.
${ }^{80}$ For example, the Jordanian member, Awn Al-Khasawneh, said that it "would be premature for the Commission,
which was called upon to legislate for a world that did not agree on the question of the death penalty, to adopt a
clear-cut opinion on the question instead of giving the States concerned discretionary power." Id. at 746 (quoting
[1991] 1 Y.B. Int'l L. Comm'n 47 , UN Doc. A/CN.4/SER.A/1991). The severity of the crimes involved in cases before
the proposed international criminal court was clearly driving part of the argument. Al-Khasawneh noted that dis-
cretion for individual states was appropriate in grave cases and said that "it would be sufficient to indicate the gravity
of the crimes in question in the Code and to include a general provision stating that those crimes would be punished
by a penalty that was in keeping with their degree of gravity." Indeed, he also noted that Protocol No. 6 to the ECHR
allowed for the use of the death penalty "in respect of acts committed in time of war or of imminent threat of war."
Id. The representative of Greece also made reference to this provision. Id. at 747 . So it seems clear that at least some
states were cognizant of the fact that the permissibility of the death penalty in times of war or cases of war crimes
was a distinct issue in international law from general abolition in domestic cases. Indeed, the issue of the gravity
of the crime was in the forefront of these discussions, as is evidenced by the Russian delegate's comments that coun-
tries might not want to extradite individuals guilty of genocide if they knew that the permanent international tribunal
could not impose the death penalty. Id. (quoting Juri G. Barsegov).

${ }^{81}$ Rolf Einar Fife, Penalties, in The InTERnAtional Criminal Court: THE MAKIng of THE Rome STATUTE 319 , 335 (Roy S. Lee ed., 1999).

${ }^{82}$ Report of the Working Group on Penalties, UN Doc. A/CONF.183/C.1/WGP/L.14/Add.3/Rev.1, in 3 UNITED NATIONS DIPLOMATIC CONFERENCE OF PLENIPOTENTIARIES ON THE ESTABLISHMENT OF AN INTERNATIONAL CRIMINAI. COURT, OFFICIAL RECORDS 315, 315 n.1, 317, UN Doc. A/CONF.183/13 (Vol. III) (1998) [hereinafter OFFICIAL RECORDS] (recommending that the president of the conference formally state that "not including the death penalty in the Statute .... [shall not] be considered as influencing, in the development of customary international law or in any other way, the legality of penalties imposed by national systems for serious crimes"). But see SCHABAS, supra note 5, at 258 (arguing that exclusion of death penalty from the Rome Statute "is a significant benchmark in an unquestionable trend towards universal abolition of capital punishment," even though retentionist countries claim that the death penalty's exclusion from the Rome Statute is a neutral factor).

${ }^{83}$ See Chairman's Working Paper, UN Doc. A/CONF.183/C.1/WGP/L.3/Rev.1, in OFFICIAL RECORDS, supra note 82 , at $314,314 \mathrm{n} .191$ (concluding as regards the death penalty that "[s] tates have the primary responsibility for prosecuting and punishing individuals for crimes falling under the subject-matter jurisdiction of the Court. In accordance with the principle of complementarity between the Court and national jurisdictions, the Court would clearly have no say on national practices in this field." See also Report of the Working Group on Penalties, supra note 82, at 317 (reiterating that national justice systems have primary responsibility for "investigating, prosecuting and punishing individuals" for crimes under the jurisdiction of the ICC). These views are mirrored in the Rome Statute, supra note 20, Art. 80, Non-Prejudice to National Application of Penalties and National Laws.

${ }^{84}$ SCHABAS, supra note 5, at 255 (reporting U.S. representative's comment that the ICC would encourage national jurisdictions to punish offenders under national laws and penalties, including the death penalty). The U.S. support for the compromise was therefore not evidence of opinio juris, but rather "a sincere effort to assist the ... search for a workable solution." Id.

${ }^{85}$ Cf. Nora V. Demleitner, The Death Penalty in the United States: Following the European Lead? 81 OR. L. REV. 131, 144 (2002) (arguing that U.S. silence over sentencing provisions at the ad hoc tribunals could be interpreted as "acquiescence to the international abolitionist movement"). But see Chairman's Working Paper, supra note 83, at 314 n.191 (noting strong desire among even retentionist countries to achieve balanced compromise).

${ }^{86}$ Fife, supra note 81 , at 326,331 . 
Finally, legislative history is a difficult avenue by which to demonstrate the subjective element. ${ }^{87}$ The most that can be learned from the legislative history of the Rome Statute is the negotiating strategies of the participants and the logrolling that produced the final result. It would accordingly appear that the negotiating history of the Rome Statute is too ambiguous to support the subjective element of opinio juris for the creation of a universal norm. ${ }^{8}$

The ICTY and the ICTR. Both Yugoslav and Rwandan law included the death penalty, ${ }^{89}$ especially for serious crimes such as murder and genocide, but certain members of the Security Council were intent on prohibiting its imposition under the tribunals' statutes. ${ }^{90}$ The most vocal complaint came from Rwandan officials, who expressed their intent to retain the death penalty for domestic prosecutions of genocide. ${ }^{91}$

The ICTY and ICTR Statutes were adopted by the Security Council under its Chapter VII powers, ${ }^{92}$ and unlike a treaty or international instrument that requires broad international agreement, a Security Council resolution only requires the agreement of nine members, including five permanent members. Moreover, the Security Council simply voted to restrict the death penalty at the ad hoc tribunals; it has never issued a binding resolution prohibiting a member state from using the death penalty. ${ }^{93}$ The Council's vote is accordingly insufficient to establish a broad pattern of opinio juris.

That the United States retains the death penalty for genocide in its domestic penal law indicates that at least one Security Council member refrained from objecting to the prohibition for diplomatic reasons, not opinio juris. ${ }^{94}$ Surely, the situation was similar for Council members such as China and Russia, which retain the death penalty in their domestic penal systems, though Russia has been abolitionist in practice since $1999 .{ }^{95}$ For state practice to count toward the creation of a customary norm, the practice must be not only widespread but also internally consistent. ${ }^{96}$ Chinese support for the prohibition in the Security Council can hardly be considered internally consistent when China retains the death penalty in its domestic penal law. Consequently, the support of such states for the statutes cannot stand for the proposition that they felt bound under international law to prohibit the death penalty for war crimes and crimes of genocide. ${ }^{97}$

87 See, e.g., Adrian T. Delmont, Note, The International Criminal Court: The United States Should Ratify the Rome Statute Despite Its Objections, 27 J. LEGIS. 335, 345 (2001) (concluding that although there is widespread support for the Rome Statute, it is insufficient opinio juris to bind nonparty states through customary international law).

${ }^{88}$ See, e.g., ILA, Customary International Law, supra note 33 , at 36.

${ }^{89}$ Although Rwandan courts were still handing down capital sentences for grave crimes in the years preceding the genocide, the government had not carried out these sentences and was effectively in a period of de facto moratorium. See supra note 11.

${ }^{90}$ See Report of the Secretary-General Pursuant to Paragraph 2 of Security Council Resolution 808, UN Doc. S/25704, at 28 (1993), reprinted in 32 ILM 1159 (1993) (recommending that the ICTY not be empowered to impose the death penalty).

91 See UN Doc. S/PV.3453, supra note 1, at 16. U.S. secretary of state Madeleine Albright was quoted as saying that although the United States agreed with Rwanda, "it was simply not possible to meet those concerns and still maintain broad support in the Council." MORRIS \& SCHARF, supra note 10, at 583.

92 Statute of the International Criminal Tribunal for Rwanda, SC Res. 955, annex, pmbl. (Nov. 8, 1994), reprinted in 33 ILM 1602 (1994) (noting that the Statute was passed pursuant to the Security Council's Chapter VII powers); Statute of the International Criminal Tribunal for the Former Yugoslavia, SC Res. 827, annex, pmbl. (May 25, 1993), reprinted in 32 ILM 1203 (1993) (same); see also Prosecutor v. Tadić, Decision on Jurisdiction, No. IT-94-1 (Aug. 10,1995 ) (upholding tribunal's jurisdiction on the basis of Security Council's Chapter VII authority to maintain international peace and security).

${ }^{93}$ If the Security Council were to do so, it would arguably make the death penalty illegal under international law. See Alvarez, supra note 53, at $408 \mathrm{n} .215$ (noting that Rwanda's use of the death penalty was consistent with international law because no binding Security Council resolution outlawed it).

${ }^{94}$ See ILA, Customary International Law, supra note 33, at 36.

${ }^{95}$ China, in AMNESTY INTERNATIONAL, REPORT 2003, available at <http://web.amnesty.org/report2003/indexeng $>$ (documenting at least 1921 death sentences and 1060 executions in 2002, though estimating that the true number may be higher).

${ }^{96}$ ILA, Customary International Law, supra note 33, at 21 (noting that " ' [i]nternal' uniformity means that each State whose behaviour is being considered should have acted in the same way on virtually all of the occasions on which it engaged in the practice in question").

97 See MORRIS \& SCHARF, supra note 10, at 583.

$$
\text { HeinOnline -- } 99 \text { Am. J. Int'l L. } 7582005
$$


As noted above, both Yugoslavia and Rwanda were supportive of the death penalty in their domestic legislation, and Rwanda was exercising its discretion to impose the death penalty while pursuing the realization of transitional justice in the wake of genocide. (There were no executions in Yugoslavia because none of its successor states implemented a prosecutorial program similar to that of Rwanda. ${ }^{98}$ ) At best, then, the negotiating history behind the ICTY and the ICTR constitutes insufficient evidence to establish a firm customary norm against imposing the death penalty for crimes of genocide. Rather, the evidence suffices only to establish that the death penalty was excluded as an option for the ad hoc tribunals because of the demands of international political realism. ${ }^{99}$ But this result is far from establishing opinio juris.

\section{Abolitionist Movements Respond to Domestic Problems}

One might believe that this analysis of the objective and subjective elements fails to take into account the most salient fact supporting the proposition that the death penalty violates international law under any circumstances: the vast number of countries that have abolished capital punishment in response to the influential and well-coordinated international abolitionist movement. The existence of this international movement would seem to be relevant for our analysis of the customary norm, even if it does not fit squarely into either the objective or the subjective category. ${ }^{100}$

However, even this evidence is problematic. The domestic prohibitions against the death penalty codified in state constitutions and state legislation are insufficient evidence to ground a norm that prohibits capital punishment for genocide. For example, the U.S. abolitionist movement is inherently domestic and fact-specific, responding to concerns about state use of capital punishment for crimes such as murder and rape. ${ }^{101}$ There is no evidence that the abolitionist movement is responding to the use of the death penalty for crimes against humanity or genocide. ${ }^{102}$ Indeed, genocide as a crime is so extrinsic to the spirit of this movement that some activists and scholars include in the abolitionist category states that reserve the death penalty for extreme moral violations, or limit its use to wartime and severe domestic emergencies. ${ }^{103}$

Abolitionist states are sometimes so fervent in their opposition that they refuse to extradite suspects to retentionist states, often on grounds of international human rights law. ${ }^{104}$ Their

${ }^{98}$ See text at notes 63-69 supra for a discussion of domestic prosecutions for genocide.

${ }^{99}$ See, e.g., BoS, supra note 34, at 237-41 (discussing cases where ICJ found no evidence of opinio juris in state practice due to, inter alia, geopolitical considerations).

${ }^{100}$ For a discussion of abolition, see generally BEYOND REPAIR?: AMERICA's DEATH PENALTY (Stephen P. Garvey ed., 2003); The DEATH PeNalty in AMERICA (Hugo Adam Bedau ed., 3d ed. 1982); PAIN, DEATH, AND THE LAW (Austin Sarat ed., 2001). See also JAN GORECKI, CAPITAL. PUNISHMENT 87-97 (1983) (discussing abolition trend in the twentieth century and tracing the movement to Jefferson and Livingston's concerns about executing innocent prisoners).

${ }^{101}$ See Jeffrey L. Kirchmeier, Another Place Beyond Here: The Death Penalty Moratorium Movement in the United States, 73 U. COLO. L. REV. 1, 3-4 (2002) (attributing the U.S. abolitionist movement to the following five factors: (1) publication of Dead Man Walking, (2) criticism of the capital punishment judicial process by Blackmun and other judges; (3) bar association resolution calling for a moratorium; (4) technological innovations for determining innocence of death row inmates; and (5) Illinois moratorium in 2000). None of these factors involve or apply to genocide, crimes against humanity, or war crimes.

${ }^{102} I d$. at 21 (noting that "[i]n some ways, the current movement is not an 'anti-death penalty' movement .... The modern movement is primarily concerned about certain aspects of the process of imposing the death penalty, not necessarily about the morality of killing convicted murderers."). Much of the scholarly literature urging abolition discusses murder, but rarely mentions genocide or war crimes. See, e.g., Jeffrey H. Reiman, Justice, Civilization, and the Death Penally: Answering van den Haag, 14 PHIL. \& PUB. AFF. 115 (1985) (arguing that although the death penalty is justified by a retributive theory of punishment, it should nonetheless be abolished in the interest of the continued civilization of society).

${ }^{103}$ See, e.g., Toni M. Fine, Comment, Moratorium 2000: An InternationalDialogue Toward a Ban on Capital Punishment, 30 Colum. HuM. RTS. L. REV. 421, 434 (1999).

${ }^{104}$ See, e.g., Soering v. United Kingdom, 161 Eur. Ct. H.R. (ser. A) (1989), reprinted in 28 ILM 1063 (1989); Richard B. Lillich, The Soering Case, 85 AfflL 128 (1996) Am. J. Int' I L. 7592005 
refusals to extradite, insofar as they are based on international legal commitments, might be evidence of state practice and opinio juris. But two points restrict the application of these developments to the formation of a customary norm. First, many of these cases, starting with Soering $v$. United Kingdom, trace their reasoning to prohibitions in the European Convention on Human Rights, a convention restricted to members of the Council of Europe. Second, these cases usually involve murder simpliciter, not genocide. It would be telling if an extensive and representative number of states refused to extradite a genocide suspect on the basis of a perceived duty under international law. ${ }^{105}$ Indeed, the Soering Court specifically noted that Article 2 of the European Convention recognizes the death penalty, ${ }^{106}$ and that even optional Protocol No. 6 only abolishes the death penalty in peacetime. ${ }^{107}$ Third, many of the countries that deny extradition to death penalty states do so because of domestic constitutional safeguards, not international legal commitments. ${ }^{108}$ Consequently, refusal to extradite is insufficient evidence of state practice when the action is not performed from a sense of international legal obligation. ${ }^{109}$

One might object that at least part of the abolitionist movement grew out of prosecutions for genocide and is consequently more relevant to our analysis. For example, the abolitionist movement in Germany has been seen as the result of widespread displeasure among the citizenry at the Allied use of the death penalty at Nuremberg. ${ }^{10}$ Indeed, the Germans abolished the death penalty by statute in $1949,{ }^{111}$ although executions continued under Control Council Law No. 10 for two more years. ${ }^{112}$ If one accepts this argument, then in at least one instance an abolitionist movement constituted a direct response to the use of the death penalty for serious offenses such as war crimes and genocide. ${ }^{113}$ As such, the abolitionist movement might be compelling evidence of opinio juris.

There are two responses to this objection. First, the analysis is limited to one state, so the most that it can demonstrate is that Germany's rejection of the death penalty was a response to its earlier use for grave crimes, but this evidence does not suggest that other countries were similarly motivated. Second, the German abolitionist movement was also informed by the

${ }^{105}$ The prosecution of Saddam Hussein might have raised these issues had he been apprehended outside Iraq.

${ }^{106}$ Although Amnesty International argued that the death penalty per se violated the European Convention, Soering's attorneys did not even advance the claim, nor did the Court so conclude. The Court held that the "death row phenomenon" was an inhuman and degrading punishment that violated the Convention. Soering, 161 Eur. Ct. H.R. (ser. A), para. 105.

107 Soering predated Protocol No. 13 and its absolute abolitionism. See text at notes 50-52 supra on the limited impact of Protocol No. 13 on this state practice analysis.

${ }_{108}$ See, e.g., United States v. Burns, 1 S.C.R. 283 (2001) (Can.) (extradition to United States without assurances that death penalty will not be applied violates Canadian Charter of Rights and Freedoms). Although the Court made reference to Canada's commitment to the global movement toward abolition, the Court's result was based on the Charter of Rights. Also, the Court noted that extradition to face the death penalty might be permissible in "exceptional circumstances," thus leaving open the possibility that it might be allowed for severe crimes such as genocide. See also Venezia v. Ministero di Grazia e Giustizia, Corte cost., 27 giugno 1996, n.223, Racc. uff. corte cost. 1996, 61, reprinted in 79 RIVISTA DI DIRITTO INTERNAZIONALE 815 (1996) (extradition violates Italian Constitution even where state officials receive assurances about death penalty); Andrea Bianchi, Case Report: Venezia v. Ministero di Grazia e Giustizia, in 91 AJIL 727 (1997).

${ }^{109}$ A domestic constitutional provision might establish opinio juris if it could be shown that the provision was adopted from a perceived duty under international law to abolish the death penalty. But in most cases the constitutional language prohibits cruel punishment generally, not the death penalty specifically.

${ }^{110}$ See Schwartz, Landsberg Cases, supra note 8, at 436-37 (noting that "[w]ith the exception of the small Communist Party and a few Social Democrats, German political leaders were united in their call for a reassessment of the Nuremberg verdicts, an end to executions, and greater leniency toward those convicted").

${ }^{111}$ The death penalty was abolished in the Grundgesetz in 1949. GRUNDGESETZ [Constitution] Art. 102.

112 SCHABAS, supra note 5, at 240 (noting the uncertainty of whether the newly formed German Constitution could legally supersede Control Council Law No. 10); THOMAS ALAN SCHWARTZ, AMERICA'S GERMANY: JOHN J. MCCLOY AND THE FEDERAL REPUBLIC OF GERMANY 168 (1991).

${ }^{119}$ See Schabas, War Crimes, supra note 17, at 741. But see Kristi Tumminello Prinzo, Note, The United States- “Capital" of the World: An Analysis of Why the United States Practices Capital Punishment While the International Trend Is Towards Its Abolition, 24 BROOK. J. INT'L L. 855, 887 (1999) (noting that two-thirds of the German population favored retaining the death penalty when it was abolished).

Heinonline -- $99 \mathrm{Am}$. J. Int'l L. 7602005 
zealous imposition of the death penalty by Nazi judges before and during the war. ${ }^{114}$ In fact, the use of the death penalty was so devoid of legal justification that Nazi judges were put on trial at Nuremberg for the Third Reich's judicial excesses. ${ }^{115}$ Thus, it is fair to say that the abolitionist movement in Germany owes just as much to the arbitrary use of the death penalty during Hitler's reign as to its use by the Allies at Nuremberg.

In part I we examined both the objective element of state practice and the subjective element of opinio juris. While at first glance both appeared to support a customary norm against the death penalty, the analysis reached beyond the usual verbal statements and treaty terms to scrutinize the actual conduct of states. Further analysis demonstrated the lack of both the uniformity of practice and the internal consistency necessary to extend the norm to cases of genocide. But that finding cannot end the analysis; it raises just as many questions as it answers. To those who oppose the death penalty tout court, the idea of reserving it for serious crimes is barbaric. Consequently, in part II we consider the rationale for retention and how it might remain consistent with general principles of international law.

\section{RECONSTRUCTING THE RETENTIONIST ARGUMENT IN CASES OF GENOCIDE}

Developing a full-fledged philosophical defense of capital punishment for genocide would be to venture well beyond both the scope and the intent of this essay. Rather, it asks whether the emerging customary norm prohibits executions for genocide. This question is logically distinct from the claim that states should execute the architects of genocide. Here the argument simply proposes that a state coming to terms with genocide may have rational reasons for resorting to the death penalty-reasons that make reference to the principles of international law.

But before this argument can be coherently reconstructed, we must first clear the way by exposing the logical fallacies that have led to the facile conclusion that the prohibition against the death penalty applies in all cases. Consequently, in the next section we explain the problems of formalistic reasoning and how it prevents a deeper understanding of the death penalty's legality in cases of genocide. This deficiency might account for the lack of scholarly work on this critical question. The rest of part II is devoted to the asymmetries between the death penalty in typical criminal contexts and the death penalty in the extreme circumstances of international criminal law; it explains why some states may feel that the unique moral gravity of genocide requires extreme measures. ${ }^{116}$

\section{Rejecting the Formalism of Naive Abolitionism}

To understand the true nature of an abolitionist norm, we must first inquire into the source of the common misunderstanding that the norm applies in all cases, even genocide. The source of this misunderstanding is not a belief but a style of reasoning: formalistic reasoning. Adopting an abstract right to life and then applying it in every situation, without analysis, is an example of formalistic thinking. The formula (the right to life) is proposed and then defended on the basis of abstract principles. Finally, it is applied in all circumstances after

\footnotetext{
${ }^{14}$ Cf. SCHABAS, supra note 5, at 238-39 (discussing role of Nazi use of death penalty in spurring Germany's abolitionist movement). Schabas presents this evidence as support for his argument that the death penalty violates customary international law. Id.

${ }^{115}$ See Schabas, War Crimes, supra note 17, at 740 (noting that the Nazi judges were convicted of implementing the "Night and Fog" decree, which called for the use of capital punishment to intimidate the population in general and the family of the criminal). Ironically, the Nazi judges themselves were spared the death penalty by the Nuremberg Tribunal. See United States v. Alstotter [The Judges. Trial], 14 Ann. Dig. 278 (U.S. Military Comm'n 1948) (finding Nazi judges guilty for enforcing arbitrary Nazi policies). Nazi judges argued, in their defense, that they had attempted to mitigate the harshness of Nazi rule. Although many defendants were executed arbitrarily, the judges maintained that many more would have died had the judiciary abstained.

${ }^{116}$ See, e.g., Diane F. Orentlicher, Settling Accounts: The Duty to Prosecute Human Rights Violations of a Prior Regime, 100 YALE L.J. 2537, 2540 (1991) (arguing that both customary and conventional international law impose duties to prosecute atrocities and bring perpetrators to justice)
} 
the heavy theoretical lifting has been performed. ${ }^{117}$ Because there is an abstract right to life, which no reasonable lawyer can deny, the death penalty is impermissible in all circumstances. But the structure of the argument is completely insensitive to context. The first premise is asserted and defended in one context, but then applied in a new context without reevaluating its robustness. While this reasoning might be legitimate in some circumstances, it generates logical mistakes in others, that is, when the original premise is born of the latent assumptions of the first context.

One way to see the formalism of the argument is to consider its circularity. It presumes as a premise the very proposition it seeks to conclude: that the legal norm includes a universal right to life. ${ }^{118}$ That is precisely what the retentionist state denies. ${ }^{119}$ The retentionist state substitutes the corollary that a genocidal criminal forfeits his right to life. ${ }^{120}$ If this corollary is to be defeated, the abolitionist must frame his objections within the context of genocide; he must be sensitive to its unique moral gravity, and cognizant of the demands of transitional justice and the concept of proportionality. The objection must respond to these considerations by carefully balancing the interests involved. Only then can a universal norm be sustained.

None of these considerations suggest that the position of the abolitionist state is untenable. But if it is to be demonstrated, it must be done by means of a new kind of argument, untainted by formalism. This new structure would do more than simply assert a principle in the abstract and then apply it to the unique moral situation of genocide and crimes against humanity. A truly sophisticated abolitionist argument would defend the rights of the criminal offender against the background of genocide and transitional justice. ${ }^{121}$ The result would be a more robust abolitionist position.

One might object that this process would place too great a burden on the abolitionist position. To defend the abolitionist position within the context of genocide is to prejudice the outcome of the debate. The retentionist position is more likely to appear legitimate when the case is genocide. In that sense it would be better to decide the question within an abstract context, because the unique moral gravity of genocide can only prejudice us and play to our emotions. But none of these objections are problematic. There is nothing inherently prejudicial about demanding a context-sensitive justification; nor is it more likely to appeal to emotions than to reason. It will, however, increase the sharpness of the argument by applying its rationale to international crimes just as it does to municipal ones.

\footnotetext{
117 See, e.g., ICCPR, supra note 24, Art. 6 (recognizing the inherent right to life); Second Optional Protocol, supra note 25 , pmbl. (noting that "all measures of abolition of the death penalty should be considered as progress in the enjoyment of the right to life"); SCHABAS, supra note 5, at 7 (discussing the right to life enshrined in the UN Charter and the lack of an explicit list of exceptions in the Charter).

${ }^{118}$ Consider, for example, the following argument in Schabas's discussion of the South African case State $v$. Makwanyane:

Justice Ismael Mahomed examined the other issues encompassed by the right to life, including abortion and euthanasia. He said it is unnecessary to resolve these matters, and that for the purposes of the case before the court, the issue should be to determine whether the right to life includes a right "not to be deliberately killed by the State, through a systematically planned act of execution sanctioned by the State as a mode of punishment and performed by an executioner remunerated for this purpose from public funds?" This readily distinguishes the question of capital punishment from other forms of state-sanctioned homicide, "for example the right of a person in life-threatening circumstances to take the life of the aggressor in self-defence or even the acts of the State, in confronting an insurrection or in the course of War."
}

Schabas, African Perspectives, supra note 11, at 43 (footnotes omitted). The problem identified by this argument is that you cannot assume the very premise that you seek to demonstrate, i.e., a universal right to life without exception. As the examples in the second part of the argument demonstrate, the whole battle must be fought around the exceptions. Almost no one accepts a universal right to life in the literal sense of that expression.

${ }^{119}$ For a defense of the theoretical point that criminals forfeit some of their moral rights, see STEPHEN KERSHNAR, DESERT, RETRIBUTION, AND TORTURE 125 (2001).

${ }^{120}$ See id.; MINOw, supra note 16, at 20; McKinley, supra note 12, at A1 (quoting Rwandans who believed that the architects of the genocide ought to die: "They killed and they have to be killed.").

121 These arguments are rare. 


\section{Transitional Justice and National Reconciliation in the Wake of Genocide}

Consider the situation faced by the newly formed Tutsi government in Rwanda after the defeat of the Hutu regime and the end of the genocide. Roughly eight hundred thousand enemies of the state, mostly Tutsi, had been killed by roving militia with machetes and lowtech armaments. ${ }^{122}$ Civilians had been hacked to death by Hutu neighbors from their own villages. ${ }^{123}$ Consequently, the number of victims and perpetrators was shockingly large. But the perpetrators were not isolated individuals acting from isolated motivations. ${ }^{124}$ The genocide had been designed by Hutu, who made cunning use of the media to incite the killings and direct attacks to places where Tutsi might be hiding. ${ }^{125}$ While many were responsible for the murders, some were more responsible than others.

After the defeat of the Hutu regime, the Tutsi government confronted the arduous task of instituting a judicial program in response to the genocide. ${ }^{126}$ Such measures were essential if the government was to forestall reprisal attacks against ethnic Hutu remaining in the country (many had fled after the Hutu government fell). ${ }^{127}$ Justice for the perpetrators of the genocide was therefore a precondition for peace and security in Rwanda (and indeed the whole region). ${ }^{128}$ Prosecutions took place on two parallel tracks: the ICTR, funded and organized by the international community, and domestic trials organized by the Rwandan judiciary. Both sets of prosecutions were hampered by the sheer enormity of the task: thousands of alleged murderers were in jail awaiting judicial determination of their fate. ${ }^{129}$ Maintaining Western standards of due process, given the limited resources of the Rwandan judicial system, would prove daunting. ${ }^{130}$ In response to these difficulties, the Rwandans instituted a system

122 See GOUREVTCH, supra note 54, at 23 (commenting that "the quiet orders of Hutu Power" combined with the machete had "made the neutron bomb obsolete").

${ }^{123}$ Id. at 22-24 (noting that Hutu from all walks of life participated in the killing); see also ROMÉO DALLAIRE (with BRENT BEARDSLEY), SHAKE HANDS WTTH THE DEVIL: THE FAILURE OF HUMANITY IN RWANDA 462 (2003) (describing the killing, by machete, of Tutsi children in front of their parents).

${ }^{124}$ GourevtrCH, supra note 54, at 22 (discussing the role that fear and obedience play in Rwandan culture); DALLAIRE, supra note 123, at 430 (describing the systematic use of rape during the genocide).

${ }^{125}$ See, e.g., Prosecutor v. Nahimana, Barayagwiza, Ngeze, Judgment and Sentence, No. ICTR-99-52-T (Dec. 3, 2003) (finding media executives guilty of, inter alia, direct and public incitement to genocide). Nahimana and Ngeze were sentenced to life in prison, while Barayagwiza received a 35-year sentence because his rights had been violated. Id., Summary, at 29-31, available at <http://www.ictr.org >. Nahimana and Barayagwiza were founding members of a media company whose radio stations broadcast Hutu extremist propaganda and directed attacks against Tutsi civilians. Ngeze owned and operated an extremist Hutu newspaper that, in the words of the court, "poisoned the minds of ... readers, and by words and deeds caused the death of thousands of innocent civilians." Id. at 30; see also GOUREVITCH, supra note 54, at 95 (describing the genocide as "the product of order, authoritarianism, decades of modern political theorizing and indoctrination, and one of the most meticulously administered states in history").

${ }^{126}$ GOUREVITCH, supra note 54, at 252 (describing the difficulty of bringing the perpetrators to justice because so many were in exile).

${ }^{127}$ Even the Rwandan law authorizing prosecution of genocide and the death penalty made explicit reference to the need to achieve reconciliation and made reference to "the adoption of specially adapted measures to satisfy the need for justice of the people of Rwanda." Organic Law No. 08/96, Aug. 30, 1996, Organization of Prosecutions for Offences Constituting the Crime of Genocide or Crimes Against Humanity Committed Since 1 October 1990, reprinted in 2 MORRIS \& SCHARF, supra note 10, at 369-70.

${ }^{128}$ See Commission on Human Rights, Report on the Situation of Human Rights in Rwanda, UN Doc. E/CN.4/ 1997/61, at 4-5 (noting that "[g] enocide and other crimes against humanity committed in Rwanda since April 1994 will continue to be of concern to the international community for some time"); UN Doc. S/PV.3453, supra note 1, at 14 (arguing that "it is impossible to build a state of law and arrive at true national reconciliation if we do not eradicate the culture of impunity which has characterized our society since 1959"); Payam Akhavan, The International Criminal Tribunal for Rwanda: The Politics and Pragmatics of Punishment, 90 AJIL 501, 505 (1996) (noting that the tribunal was established under the Security Council's Chapter VII powers and that "punishment of past human rights abuses was viewed as an essential element of postconflict peace building in a society destroyed by division and strife").

${ }^{129}$ The total number is roughly 125,000. Mark A. Drumbl, Punishment, Postgenocide: From Guilt to Shame to Civis in Rwanda, 75 N.Y.U. L. REv. 1221, 1233 (2000) (describing Rwanda's judicial system).

${ }^{130}$ AMNESTY INTERNATIONAL, RWANDA: THE TROUbled COURSE OF JUSTICE 2 (2000) (enumerating arbitrary arrests, delayed trials, and harsh prison conditions); Mark A. Drumbl, Rule of Law Amid Lawlessness: Counseling the Accused in Rwanda's Domestic Genocide Trials, 29 COLUM. HUM. RTS. L. REV. 545, 548 (1998) (noting the "haphazard

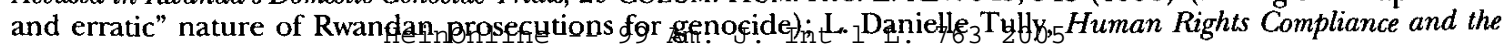


of community trials-called gacaca - that emphasized confessions in return for community reconciliation. ${ }^{131}$

The death penalty constituted an integral part of Rwanda's domestic penal response to the genocide. Because the death penalty remained in force for regular crimes under Rwandan law, victims of the genocide considered capital punishment an essential element of the judicial program. It would be absurd for the architects responsible for killing eight hundred thousand civilians to receive lighter sentences than those responsible for killing fewer civilians, or for aiding and abetting the genocide. ${ }^{132}$ In Rwandan culture, severe crimes deserve severe penalties. ${ }^{133}$

While individuals convicted at the ICTR would escape the death penalty, several individuals convicted by the Rwandans were executed for their crimes. ${ }^{134}$ Indeed, several defendants were hauled into a football stadium and executed in public before thousands of Rwandans. ${ }^{135}$ This episode was widely cited by abolitionists as evidence of the bloodthirsty and vengeful character of the Rwandan judicial system. ${ }^{136}$ But this view of the episode was informed and colored not only by Western attitudes about punishment, but, more important, by a Western population that had never witnessed the slaughter of eight hundred thousand civilians. To paint the executions as nothing more than a demand for revenge is to trivialize the difficult task of repairing a national culture in the wake of genocide. In essence, a deal was struck. Reprisal attacks against ethnic Hutu would not be tolerated. In exchange, though, the Hutu perpetrators of the genocide would receive swift and severe justice for their crimes. Had the Rwandan government ignored the public demand for severe punishment, the country might have fallen back into ethnic violence. ${ }^{137}$ The use of the death penalty in this limited context, applied in a limited fashion, was a function of the extreme demands of transitional justice. The unique moral gravity of genocide gave birth to a unique set of jurisprudential considerations. ${ }^{138}$ One must evaluate the legality of the death penalty under international law against these background considerations. Failure to do so would minimize the legitimate and severe difficulties of transitional justice.

This situation is now repeating itself in Iraq, as the new Iraqi government struggles with the demands of transitional justice. Saddam Hussein maintained his rule over disparate ethnic

Gacaca Jurisdictions in Rwanda, 26 B.C. INT'L \& CoMP. L. REv. 385, 402 (2003) (noting that the utter devastation of the genocide has made adhering to international fair trial standards "nearly impossible").

${ }^{131}$ See Drumbl, supra note 129, at 1263 (discussing the "ability of gacaca to serve as a conduit for postgenocidal reintegrative shaming"); Tully, supra note 130, at 395-401 (describing gacaca courts as the "last hope" for the Rwandan judicial system's attempt to deal with the genocide).

132 UN Doc. S/PV.3453, supra note 1, at 16 (Rwandans withdrawing support for the ICTR because of, inter alia, the disparity in sentencing between the Rwandan courts and the proposed tribunal); see also Christina M. Carroll, An Assessment of the Role and Effectiveness of the International Criminal Tribunal for Rwanda and the Rwandan National Justice System in Dealing with the Mass Atrocities of 1994, 18 B.U. INT'L L.J. 163, 177 (2000).

${ }^{133}$ GOUREVITCH, supra note 54, at 254-55.

${ }^{134}$ See supra note 12.

${ }^{135}$ McKinley, supra note 12. Since the public executions in the soccer stadiums, Rwanda has not performed a single execution, although other defendants have received death sentences from Rwandan courts.

${ }^{136}$ See, for example, Justice, Rwandan-Style Public Executions May Bring Other Bloodshed, HERALD (Glasgow), Apr. 25, 1998, at 16, an editorial, which states:

From the considered perspective of liberal Western democracy, pumping machine-gun bullets into convicted criminals for up to five minutes, then finishing them off with pistol shots to the head as they twitch on the stakes to which they are bound blindfold, hardly seems a reasonable way to make the point that human life is sacred.

See also McKinley, supra note 12 (noting concerns of human rights activists); Ann M. Simmons, Rwanda Plans Public Executions for Genocide, L.A. TIMES, Apr. 23, 1998, at A4 (quoting anonymous UN official on Rwanda's "lust for vengeance" and its impact on subsequent genocide convictions).

${ }^{137}$ While the region continues to be engulfed in ethnic conflict, Rwanda as a whole has remained comparatively stable. See UN Doc. S/PV.3453, supra note 1, at 15 (Rwandan representative stating that " $[t]$ he national reconciliation of the Rwandese can be achieved only if equitable justice is established and if the survivors are assured that what has happened will never happen again").

${ }^{138}$ For a discussion of the unique moral gravity of genocide, see RICHARD J. BERNSTEIN, RADICAL EVIL: A PHILOSOPHICAL INVESTIGATION (2002) Hinonline -- 99 Am. J. Int'l L. 7642005 
groups by exercising totalitarian control. Now, in the absence of a strong central government, ethnic divisions are reemerging with increased intensity. Ethnic groups that were targeted by Hussein, such as the Kurds, are seeking justice for their victimization. ${ }^{139}$ One place to find that justice is in Hussein's trial for genocide by the new government. Furthermore, a prison sentence in lieu of capital punishment would not be viewed as an adequate response for acts of genocide that claimed the lives of 150,000 Shiites and 5000 Kurdish civilians. ${ }^{140}$ If justice cannot be found in that venue, the country runs the risk of returning to ethnic violence. Kurds and Shiites may seek revenge against ethnic groups, such as the Sunnis, who were favored under Hussein's regime. The consequences for national reconciliation could be devastating.

One might object at this point that the appeal to transitional justice-just like the appeal to majoritarian decision making-proves too much. Any conduct might be justified on the ground that transitional justice demands it. If we can justify any potential human rights abuse by claiming that the populace will accept nothing less, then we have effectively eroded the concept of human rights as something immune from balancing by majoritarian decision making. ${ }^{141}$ Any number of abuses, including torture and ethnic cleansing, might be spuriously justified on these grounds. This point exposes a conceptual problem of the above argument.

The argument must be re-formed to take this objection in to account. It is not so much that transitional justice, by itself, justifies the death penalty in response to genocide. No such claim is made in this article. Indeed, the position here is more subtle: retentionist states coping with the aftermath of genocide face unique challenges that must be considered when evaluating the death penalty's legality under international law. This position is not to suggest that these unique challenges will overpower any human rights commitment. Rather, it suggests that the analysis must be sufficiently complex to deal with these issues. A blanket and unthinking prohibition against capital punishment-regardless of crime, regardless of circumstance-does not fill the bill. Only a robust and complex analysis sensitive to the horror of genocide and the demands of transitional justice would be sufficient to meet this standard.

\section{The Demands of Proportionality}

As suggested above, the demands of transitional justice in the wake of genocide cannot, by themselves, fully support the retentionist position. More conceptual content must be added to the justification so as to put the best possible gloss on retentionist policies. The concept of proportionality provides that conceptual content. ${ }^{142}$ Prison sentences might fail to meet the demands of transitional justice for retentionist states because mere imprisonment would not be a proportional response to genocide. ${ }^{143}$ To arrive at an interpretation

\footnotetext{
${ }^{139}$ Possible charges against Hussein include his gassing of the Kurds in 1988 and atrocities committed during the Shiite uprising in 1991 . However, the Iraqi government has indicated that it may wish to proceed with a more limited prosecution of specific crimes instead of documenting all cases of genocide and crimes against humanity. See John F. Burns, First Court Case of Hussein Stems from ' 82 Deaths, N.Y. TIMES, June 6, 2005, at Al.

${ }^{140}$ Although the Coalition Provisional Authority suspended the death penalty upon taking control of Iraq, it was. immediately reinstated after Iraq regained its sovereignty.

${ }^{141}$ See Drumbl, supra note 130, at 635-36 (discussing the role of genocide trials as public catharsis and arguing that "[i]t is even more unfortunate to use these trials as a tool to bully the population in the absence of economic and social reforms"). But for a unique exploration of the advantages of local genocide prosecutions over international fora, see Alvarez, supra note 53, passim. Cf. Antonio Cassese, On the Current Trend Towards Criminal Prosecution and Punishment of Breaches of International Humanitarian Law, 9 EUR. J. INT'L L. 2, 7 (1998) (arguing for the primacy of international prosecutions).

142 For a general discussion of proportional punishment, see C. L. TEN, CRIME, GUILT, AND PUNISHMENT 158 (1987) (distinguishing between thick and thin versions of the proportionality principle). Ten's version of the thick proportionality principle requires that punishments reflect the moral gravity of the offense relative to other offenses, but does not necessitate an appropriate level of punishment in absolute terms. Id. at 159.

143 See, e.g., RAMA MANI, BeYOND RETRIBUTIgN: SEEKJNG JUSTICE IN THE SHADOWS OF WAR 98 (2002).
} 
of this attitude, we need to understand the conceptual basis for it. That requires a digression into the different underlying theories of punishment. ${ }^{144} \mathrm{We}$ will then be able to evaluate the proportionality claim and the circumstances under which it might be persuasive. If it truly has no merit, then the argument from transitional justice would fail. But if it does have merit, we must enumerate the conditions under which it might succeed.

Abolitionists have argued that the death penalty cannot be justified under any of the major philosophical theories that justify capital punishment: deterrence, retribution, expression, and reconciliation. ${ }^{145}$ From the point of view of the retentionist state, such objections, while plausible in the typical criminal context, are at their weakest when dealing with genocide. The enormity of the crime arguably changes the moral calculations significantly. The principled abolitionist must contend with this reality. ${ }^{146}$

In considering the four major theories of punishment and their impact on the problem of genocide, we do not defend the morality of the death penalty. Rather, the analysis, as always, centers on its legality. Why do retentionist states believe that the death penalty is the only means to achieve transitional justice in the case of genocide? If it turns out that at least one of these theories of punishment supports the retentionist contention that the death penalty is necessary to achieve transitional justice, then we will have a better understanding of the retentionist argument. ${ }^{147}$ Moreover, we will also be in a better position to investigate, in part III, whether there is a paradigm under international law to express the retentionist position.

Deterrence. The evidence on the death penalty as a deterrent is mixed and its success remains a point of contention in the social sciences. ${ }^{148}$ If the empirical conclusions are uncertain in the case of domestic criminal justice ${ }^{149}$ the evidence is likely to be equally contentious in cases under international criminal law. Arguably, there are too few cases of genocide ${ }^{150}$ to form valid empirical conclusions about the deterrent effects of punishments for it. But a few a priori observations are possible. Hitler probably would not have been deterred by the death penalty at a Nuremberg-style tribunal. Those who are inclined to commit acts of genocide are operating at the margins of morality and are not susceptible to the usual constraints. ${ }^{151}$

But the fact that a war criminal would probably not be deterred by punishment is not-by itself-enough to conclude that the deterrent effect is negligible. The deterrent effect is best

\footnotetext{
${ }^{144}$ For a general discussion of theories of punishment, see MATT MATRAVERS, JUSTICE AND PUNISHMENT: THE RATIONAle Of COERCION (2000); PHILOSOPHY OF PUNISHMENT (Robert M. Baird \& Stuart E. Rosenbaum eds., 1988).

145 This list of theories of punishment is not meant to be exclusive.

146 See Alvarez, supra note 53, at 408-09 (arguing that little attention is paid to the theories of punishment underlying the ad hoc tribunals and that "[i]nternational lawyers do not appear to be concerned about grounding the ad hoc tribunals' sentences, including the prohibition on the death penalty, in a coherent moral or philosophical framework").

${ }^{147}$ The theories of punishment discussed in this part are not mutually exclusive. Elements from each may be mutually supporting and might be combined to form novel theories of punishment. Rarely are accounts of punishment entirely retributive, consequentialist, or expressive. Cf. Jerome Michael \& Herbert Wechsler, A Rationale of the Law of Homicide II, 37 CoLUM. L. REV. 1261, 1262 (1937) (suggesting that punishment may simultaneously promote goals of deterrence, incapacitation, and reformation).

${ }^{148}$ See, e.g., Mary Sigler, Contradiction, Coherence, and Guided Discretion in the Supreme Court's Capital Sentencing Jurisprudence, 40 AM. CRIM. L. REV. 1151, 1158 (2003) (arguing that there is no persuasive evidence for finding a deterrent effect for capital punishment); Peter Passell, The Deterrent Effect of the Death Penalty: A Statistical Test, 28 STAN. L. REV. 61 (1975) (reaching a similar conclusion on the basis of a statistical analysis). But see Ernest van den Haag, On Deterrence and the Death Penalty, 60 J. CRIM. L. \& CRIMINOLOGY 141 (1969) (noting that although the deterrent effects of the death penalty are unproven, so too are the deterrent effects of longer prison sentences over shorter ones). It is well beyond the scope of this article to evaluate the evidence with sophistication.

${ }^{149}$ For a classic consequentialist justification of punishment on the principle of utility, see generally JEREMY BENTHAM, INTRODUCTION TO THE PRINCIPLES OF MORAIS AND LegISLATION (1789). See also John Rawls, Two Concepts of Rules, 64 PHIL. REV. 3, 5 (1955) (arguing that punishment as an institution, as opposed to individual acts of punishment, might be justified by utilitarianism). For an innovative example of a consequentialist theory of punishment that is nonutilitarian, see generally JOHN BRAITHWAITE \& PHILIP PETTIT, NOT JUST DESERTS: A REPUBLICAN THEORY OF CRIMINAL JUSTICE 69-71 (1990).

${ }^{150}$ See supra notes 53-54 and corresponding text.

${ }^{151}$ See, e.g., Walter Berns, The Morality of Anger, in PHILOSOPHY OF PUNISHMENT, supra note 144, at 85, 86.
} 
construed as the likelihood that the act will be repeated multiplied by the severity of the act. Thus, a punishment might be justified when there is a high probability that a minor crime will be prevented. ${ }^{152}$ But a punishment might also be justified when there is a low probability that a very severe crime will be prevented. For example, society might be more willing to accept high costs to prevent murder than to prevent jaywalking. And a people might be even more willing to pursue an elusive deterrent effect to prevent a moral catastrophe.

For example, the leaders of a country such as Rwanda, in dealing with the aftermath of genocide, may understand that the deterrent effects of executing genocidal criminals are speculative at best, yet the cost of ignoring the possibility of deterrence might simply be too high. The situation in Iraq prompts a similar line of reasoning. Transitional societies must establish the rule of law and failure to do so may come at an enormous cost: the revival of ethnic violence and genocidal attacks. Perpetrators must be put on notice that attacks will be punished; victims must forgo reprisals. Although the deterrent effect of executions may be speculative, it may nonetheless have been rational for Rwanda to pursue them because there was some chance that the policy would reestablish the rule of law. Similarly, Iraqi leaders may believe that an effective program to prosecute war crimes is necessary to convince warring ethnic groups to forgo violence and that transitional justice would be incomplete without capital punishment.

The retributive theory. Opponents of the death penalty often claim that a prison sentence is sufficient to achieve retributive goals. ${ }^{153}$ While this claim might hold true for ordinary crimes, the calculation changes for genocide. Retributive theories begin with the presumption that moral normalcy can be reestablished only when the perpetrator suffers punishment for his own actions. ${ }^{154}$ The punishment does not deter future crimes-the criminal deserves to be punished and the act of punishment is intrinsically worthwhile. ${ }^{155}$ Importantly, the retributive theory implies some degree of proportionality; otherwise, the offender's immoral nature is insufficiently chastised. ${ }^{156}$ It would accomplish nothing to sentence a murderer to a day in jail and send him on his merry way. Similarly, how would a short prison sentence reestablish the moral order when the perpetrator was responsible for the genocide of an entire ethnic group? ${ }^{157}$ Arguably, the moral severity of genocide indicates that traditional methods of punishment might be inadequate to the retributive task.

\footnotetext{
${ }^{152}$ Subject of course to the constraint that the punishment is not disproportionate to the offense.

${ }^{153}$ See generally H. L. A. HART, Responsibility and Retribution, in PUNISHMENT AND RESPONSIBILITY: ESSAYS IN THE Philosophy Of LAW 210 (1968); ROBERT NOZICK, PHILOSOPHICAL EXPLANATIONS 370 (1981) (arguing that retributive punishment is "an act of communicative behavior"); J. D. Mabbott, Punishment, 48 MIND (n.s.) 152, 162-63 (1939) (defending retributive theory of punishment because "the infliction of a particular punishment should not be determined by the good that particular punishment will do either to the criminal or to 'society"); Michael S. Moore, The Moral Worth of Retribution, in RESPONSIBILITY, CHARACTER, AND THE EMOTIONS 179, 180 (Ferdinand David Schoeman ed., 1987) (arguing that the "moral culpability" of the criminal not only justifies society's punishment, but in fact gives society a duty to punish). But see Russ Shafer-Landau, The Failure of Retributivism, 82 PHIL. STUD. 289 (1996).

${ }^{154}$ See Immanuel KaNT, The Metaphysics of Morals, in KaNT: POlITICAL Writings 132, 154-55 (Hans Reiss ed., Cambridge Univ. Press, 2d ed. 1991) (1797) (concluding that "[j]udicial punishment can never be merely a means of furthering some extraneous good for the criminal himself or for civil society, but must always be imposed on the criminal simply because he has committed a crime").

${ }^{155}$ See, e.g., Moore, supra note 153, at 184 (arguing that moral desert is both a necessary and sufficient condition for punishment).

${ }^{156}$ See KANT, supra note 154, at 155 (arguing that only the "law of retribution" can determine the "quality and quantity of punishment" and it must be determined in court); see also IMMANUEL KANT, THE PHILOSOPHY OF LAW 198 (W. Hastie trans., 1974) (1887) (arguing that criminal sentences must be proportionate to the "internal wickedness" of the offender). Indeed, Kant marshals this argument in favor of capital punishment, suggesting that in the case of murder, there is "no juridical substitute or surrogate, that can be given or taken for the satisfaction of Justice." Id. Nozick refers to the program of proportional punishment as "retributive matching punishment." NOzICK, supra note 153 , at $371 \& \mathrm{n} .^{*}$.

${ }^{157}$ Cf. Hugo Bedau, Capital Punishment, in MATters OF LifE AND DEATH 188 (Tom Regan ed., 2d ed. 1986) (arguing that even the death penalty fails to satisfy the retributive standard and that nothing short of torture would be sufficient). HeinOnline -- $99 \mathrm{Am}$. J. Int'l L. 7672005
} 
When the Rwandan government executed perpetrators of the genocide in 1998, onlookers claimed that the defendants "deserved" to die for their crimes. ${ }^{158}$ The claim was not consequentialist, but deontic. ${ }^{159}$ The moral desert of the perpetrators not only justified the executions; it somehow demanded them. ${ }^{160}$ But some theorists criticized this approach and argued that the retributive theory proved too much. ${ }^{161}$ The genocide was so heinous that not even execution could fulfill the retributive goal. Only torture-or even greater, perhaps unimaginable punishments-could satisfy the retributive theory. ${ }^{162}$ Perhaps the only true punishment would be to do to the perpetrators what they had done to the victims. But this approach, of course, was impossible. These arguments were not presented as a means of justifying torture but, rather, as a reductio ad absurdum showing that the retributive theory must be wrong. Similar criticisms appeared in the Iraqi context, ${ }^{163}$ especially by fervent abolitionist states such as Germany and Spain. ${ }^{164}$

These objections almost certainly fail. The retributive theory does not require that the perpetrators receive as a punishment what the victims suffered as a crime. It simply suggests that punishments are not justified by their positive consequences for society but, rather, by an a priori duty of society to punish individuals according to their moral desert. Furthermore, it explains why the victims may consider imprisonment an unacceptable punishment for genocide: the perpetrators of this crime arguably suffer from the worst kind of moral desert possible. This fact cannot be ignored.

The expressive theory: Under this theory, ${ }^{165}$ the institution of punishment serves to express society's disapproval of a criminal act. ${ }^{166}$ This concept turns the institution of punishment, at least partly, into a psychological affair. ${ }^{167}$ While the institution of punishment includes many different physical factors-judges, lawyers, criminal codes, prisons-all of them boil down to elaborate practices of praising and blaming. The abolitionist might argue that expressing our disapproval for certain conduct can be accomplished with mere symbolic examples of punishment. Such theories have been used to endorse innovative experiments in punishment, such as public shaming, ${ }^{168}$ and also to criticize severe forms of punishment, such as lengthy prison sentences and capital punishment. ${ }^{169}$

It is unclear, however, why the expressive theory of punishment would require forgoing the death penalty in all cases. Certainly, expressive theories of punishment will be sensitive to the proportionality requirement. ${ }^{170}$ If the crime is as severe as genocide, only extreme

\footnotetext{
${ }^{158}$ See supra notes $119-20$ and corresponding text.

${ }^{159}$ See MANI, supra note 143, at 34.

${ }^{160}$ See UN Doc. S/PV.3453, supra note 1, at 16.

${ }^{161}$ See, e.g., Shafer-Landau, supra note 153.

162 Id.

${ }^{163}$ See, e.g., Jonathan Finer \& Naseer Nouri, Capital Punishment Returns to Iraq, WASH. POST, May 26, 2005, at A16 (noting criticisms by human rights groups about the use of the death penalty by the new Shiite-led government).

${ }^{164}$ Meanwhile, Iraqi citizens applaud the reinstitution of the death penalty and argue that it is the only appropriate punishment for Saddam Hussein's genocide. $I d$.

${ }^{165}$ See, e.g., NOzICK, supra note 153, at 364 (analyzing the Gricean communicative behavior underlying retributive punishment); Joel Feinberg, The Expressive Theory of Punishment, 49 MONIST 397 (1965).

${ }^{166}$ MATRAVERS, supra note 144, at 88 (discussing "the idea that wrongdoing appropriately evokes a response of resentment and an expression of criticism is familiar and convincing"); NozICK, supra note 153, at 370 (arguing that punishment sends the message "this is how wrong what you did was"). The expressive theory of punishment is not necessarily logically distinct from the retributive theory and in some forms can be a variant of it. See, e.g., J. Hampton, The Moral Education Theory of Punishment, 13 PHIL. \& PUB. AFF. 208, 208 (advocating an expressive theory of retribution).

${ }^{167}$ Feinberg, supra note 165 , at $397-98$.

${ }_{168}$ Compare Katharine K. Baker, Sex, Rape, and Shame, 79 B.U. L. REV. 663, 706 (1999) (arguing for public shaming as a strategy to fight sexual violence), with Toni M. Massaro, Shame, Culture, and American Criminal Law, 89 MICH. L. REV. 1880, 1943 (1991) (arguing against public shaming as an effective penal reform). See also Drumbl, supra note 129, at 1263 (describing shaming model as a method of national reconciliation).

${ }^{169}$ However, nothing inherent in the theory precludes support for severe punishments. See TEN, supra note 142 , at $42-43$.

${ }^{170} I d$ at 50.

Heinonline -- 99 Am. J. Int'l L. 7682005
} 
forms of punishment may adequately express society's condemnation of the evil act. ${ }^{171}$ While innovative institutions of public shaming may suffice for some domestic crimes, a society victimized by genocide may require more extensive avenues of expression. This is not to suggest that the death penalty is the required punishment for genocide under the expressive theory of punishment. But it does suggest that a retentionist state subscribing to the expressive theory might legitimately believe that the death penalty is the only proportional response to an extreme rending of the moral fabric.

Reconciliation. One might also view punishment as the avenue for repairing the breach to community peace caused by the moral infraction. Naturally, the required punishment will be relative, to some degree, to the community involved. ${ }^{172}$ True reconciliation would be difficult to achieve if the punishment were not rooted in local practices and attitudes-about both the morality of the crime itself and the methods of punishment in response to it. Many sociological factors will influence this calculation, ranging from religious attitudes and cultural practices to the political structure of the community. In the case of Rwanda, true reconciliation would be impossible without local forms of punishment, ${ }^{173}$ and the death penalty is available under Rwandan law for severe crimes such as murder. ${ }^{174}$ To Rwandans, excluding the death penalty from international tribunals with jurisdiction to prosecute crimes of genocide would do little to advance their interest in reconciliation. ${ }^{175}$ Still, that some communities take this position does not mean that the death penalty ought to be used in all communities. Where capital punishment forms the backdrop of cultural practice, the reconciliatory theory may support it. The calculation obviously changes in the case of genocide. When the rift in the community is that much larger, the punishment required to mend that rift may be correspondingly large. In the case of Iraq, the difficult process of getting diverse ethnic groups to cooperate in a central government requires repairing damage to the moral fabric of society caused by Saddam Hussein's genocide. Bringing those groups together cannot be done unless Shiites and Kurds witness an accounting, with appropriate sanctions, for Hussein's crimes.

But what if the calculation requires a punishment that is so severe that it offends the international community's sense of decency or human rights? In these circumstances, a conflict is posed between the demands of justice and the rights of perpetrators. ${ }^{176}$ If one side must give way, who should bear the burden of resolving the conflict? Should the community be forced to forgo reconciliation because genocide is so extreme that the usual punishment - a prison sentence-is inadequate? Or should the war criminal forgo his right to the usual punishment?

\section{The Centrality of Proportionality}

Having elucidated that the concept of proportionality is central regardless of one's theory of punishment, ${ }^{177}$ we can conclude that a retentionist state may have legitimate jurisprudential

\footnotetext{
171 This would constitute a charitable reading of Rwanda's public execution of its criminals. See GOUREVTCH, supra note 54, at 254-55 (questioning whether Rwandan offenses were less extreme than the World War II crimes that were punishable by death); McKinley, supra note 112; Orentlicher, supra note 116 (discussing the obligatory nature of punishment for atrocities under international law).

172 See, e.g., Drumbl, supra note 129, at 1263.

${ }^{173}$ See Alvarez, supra note 53, at 409 (asking, "How exactly does the ICTR confer the 'highest form of justice' when it fails to permit (and may even help prevent) the execution of someone who has ordered or participated in the death of thousands?" (footnote omitted)).

${ }^{174}$ Cf. Schabas, A frican Perspectives, supra note 11, at 33-35 (arguing that the standard attribution of harsh penalties to African peoples is the result of inaccurate history). According to Schabas, capital punishment was brought to Africa by colonialism and precolonial African tribes rarely executed criminals. Id.

${ }^{175}$ Indeed, this was the major reason for Rwandan opposition to the ICTR. The paradoxical discrepancy in sentencing latitude between the domestic courts and the ICTR has been almost universally condemned in the scholarly literature. Admittedly, the condemnation was sometimes followed by a plea for universal abolition of the death penalty. See, e.g., Carroll, supra note 132, at 177 (noting that Rwanda's concern in this area has not been addressed); see also Alvarez, supra note 53, at 409 n.218.

176 This issue is explored in greater depth in part III infra.

177 See MORRIS \& SCHARF, supra note 10, at 584 (noting that international law offers only proportionality as a principle for determining sentenfes Hufder internatjignah criminaltlaw) $)_{L} .7692005$
} 
reasons for retaining the death penalty in cases of genocide. The death penalty might be a central aspect of its program of transitional justice. International law recognizes that states have a bona fide need to maintain internal security, ${ }^{178}$ but they cannot do so without public confidence in the administration of justice.

Public confidence in the administration of justice is influenced by the bedrock legal and moral principle that punishment should be proportional to the gravity of the offense. ${ }^{179}$ Obviously, there can be no equity in a legal system that hands down severe sentences for minor crimes. ${ }^{180}$ A retentionist state may also believe that there can be no justice in a system with lax sentences for major crimes. Ideally, a system is constructed in such a way that punishments vary by degree and intensity with the severity of the crime, so that no criminal can reasonably complain of abnormally harsh treatment in comparison to another prisoner. ${ }^{181}$ The crime of genocide poses an obvious difficulty for a criminal justice system (whether national or international) that seeks overall proportionality. Can a ten-year prison sentence adequately punish someone responsible for killing thousands of civilians, perhaps even tens of thousands of civilians? ${ }^{182}$ Retentionist states do not believe so, and consequently feel compelled to resort to capital punishment. ${ }^{183}$ The retentionist may not apply it in all cases but reserve it for extreme situations so as to preserve proportionality in sentencing.

One might object that the goals of proportionality in a criminal justice system do not justify abrogating the right to life. While proportionality is a laudable goal, it is just that: a community goal that cannot serve as an excuse for violating human rights. Rights are precisely the opposite: trumps that can be played against utilitarian considerations. ${ }^{184}$ Regardless of the benefit to the community, a society cannot abrogate the human rights of its members. ${ }^{185}$ Similarly, no benefit to our justice system can justify a death sentence that violates a criminal's right to life. ${ }^{186}$ Rights are, by definition, absolute, inviolable, and immune from balancing. ${ }^{187}$

The retentionist state might advance two responses to this objection. First, the objection is question begging inasmuch as it assumes the very thing we are trying to determine: whether

178 See, e.g., UN CHARTER Art. 51 (codifying right to collective self-defense); ICCPR, supra note 24, Art. 12(3) (allowing exceptions only when provided for "by law [and] necessary to protect national security, public order (ordre public), public health or morals or the rights and freedoms of others").

${ }^{179}$ Another way of understanding the centrality of proportionality is to consider cruel and unusual punishment. How would one evaluate this claim without making reference to proportionality? Punishments are usually cruel and unusual when they are completely out of proportion to the offense concerned.

${ }^{180}$ The requirement of proportionality in criminal sentencing is codified in Article 67 of the Fourth Geneva Convention (prosecution must be "in accordance with general principles of law, in particular the principle that the penalty shall be proportionate to the offence"). Geneva Convention Relative to the Protection of Civilian Persons in Time of War, Aug. 12, 1949, Art. 67, 6 UST 3516, 75 UNTS 287. Interestingly, Article 67 does not distinguish between sentences that are too severe and sentences that are too lenient.

${ }^{181}$ Two kinds of proportionality are at work here. The first, what we will call offense gravity, involves proportionality between the gravity of the crime and the severity of the sentence. Article 7 of ICCPR, supra note 24, codifies this kind of proportionality, indicating that there should be some sort of intuitive relationship between the crime and the sentence. Severe violations of the moral order call for severe punishment. The second kind of proportionality we will call defendant comparability, the proportionality between various sentences. Punishments of a group of defendants ought to be proportional in the sense that of those accused of the same crime, the more culpable ought to receive the longest sentences. Ideally, the punishments should reflect a moral hierarchy among the perpetrators. These proportionality requirements are difficult to satisfy in international criminal law when the crimes adjudicated by the tribunals are writ large.

${ }_{182}$ See UN Doc. S/PV.3453, supra note 1, at 16 (comments by Rwandan representative on necessity of capital punishment).

${ }^{183}$ Id:; see also MANI, supra note 143, at 98 (noting that Rwanda victims "feel that perpetrators are being privileged over victims").

${ }^{184}$ E.g., Ronald M. Dworkin, Rights as Trumps, in THEORIES OF RIGHTS 153, 153 ( Jeremy Waldron ed., 1984) (stating simply that "[r]ights are best understood as trumps over some background justification for political decisions that states a goal for the community as a whole").

${ }^{185} \mathrm{Id}$. at 166 (describing a rights claim as implying that a decision is wrong because it fails to take into account the damage it might do to a few individuals).

${ }^{186}$ See SCHABAS, supra note 5, at 25-28 (discussing the origins of the right to life in international law).

${ }^{187}$ Dworkin, supra note 184 , at 166 . Heinonline -- $99 \mathrm{Am}$. J. Int'l L. 7702005 
criminals, in all circumstances, have an absolute right to life. It is precisely that kind of unqualified right that the retentionist state would reject. ${ }^{188}$ While the right to life is a generalized goal recognized in international human rights instruments, ${ }^{189}$ this recognition does not signify an absolute right without qualification or without sensitivity to context. The retentionist state denies the claim that human beings have an absolute right to life regardless of their actions and moral culpabilities. ${ }^{190}$ Just as a soldier gives up his right to life when he carries arms on the battlefield, so the architect of genocide gives up his right to life when he conspires to murder an entire ethnic group. ${ }^{191}$ Second, the retentionist asks, should the criminal gain the advantage of this human rights norm? If there is a genuine conflict between a retentionist state's interest in pursuing justice in the wake of atrocity and the criminal's right to life, who ought to sacrifice his needs-the victim or the perpetrator? The architect of mass genocide should not be able to take advantage of our liberal and humane attitudes about punishment. Otherwise, it is the victims who will bear the burden of our liberal attitudes by sacrificing their legitimate interest in a proportional response to atrocity. ${ }^{192}$

\section{BALANCING THE Human Right to LiFE AND STATE INTERESTS}

While a thick literature has developed on the retention of the death penalty in general, there is a paucity of scholarship evaluating the retentionist policy specifically in cases of genocide. ${ }^{193}$ It is in this arena that a state may have unique legal reasons for retaining the death penalty that are not implicated in other areas of criminal jurisprudence. ${ }^{194}$ What is missing is a conceptual scheme that helps to explain the special legal rationale for a retentionist policy in cases of genocide.

The cause of the problem is an intractable impasse. The abolitionist anchors her argument in universal human rights norms that locate the individual as the primary interest holder. ${ }^{195}$ The retentionist, on the other hand, anchors her argument in the state's interest in pursuing a program of transitional justice in the wake of genocide. ${ }^{196}$ Not only does the conflict appear irresolvable as an empirical matter; it is unclear how to conceptualize a matrix that allows a coherent comparison of the two interests. The arguments seem mutually exclusive because they are based on incompatible premises.

In the following discussion, we seek and then develop an appropriate conceptual matrix within which to evaluate the competing claims of the abolitionist and the retentionist. This goal is motivated by several factors. First, as indicated above, the retentionist argument implicates novel legal issues when dealing with genocide. Second, academic arguments about the

\footnotetext{
${ }^{188}$ See, e.g., United Nations Norms and Guidelines in Criminal Justice, UN Doc. A/CONF.87/9, at 3 (1980) [hereinafter Secretariat Working Paper] (discussing exceptions to the right for those who commit crimes against humanity).

${ }^{189}$ Universal Declaration of Human Rights, GA Res. 217A (III), Art. 3, UN Doc. A/810, at 71 (1948) ("Everyone has the right to life, liberty and the security of person.").

${ }^{190}$ See Secretariat Working Paper, supra note 188, at 3.

${ }^{191}$ See KERSHNAR, supra note 119 , at 125.

192 See MANI, supra note 143, at 85 (noting that "restoring the rule of law will be meaningful only if it is synonymous with justice").

${ }^{193}$ In the United States, the retentionist argument is taken for granted, while in Europe, it is considered so weak that the issue is considered close to settled. The result is a lack of serious development of the retentionist position. But see Schabas, War Crimes, supra note 17, at 752.

194 See infra notes 227-42 and corresponding text.

${ }^{195}$ SCHABAS, supra note 5, at 23 (anchoring argument in the individual's universal right to life).

196 See UN Doc. S/PV.3453, supra note 1; see also Draft resolution, UN DEP'T OF ECONOMIC \& SOCIAL AFFAIRS,

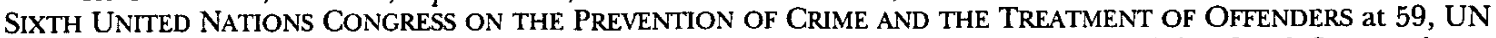
Doc. A/CONF.87/14/Rev.1, UN Sales No. E.81.IV.A (1981) ("recognizing the sovereign right of each State to determine its own criminal policy," although encouraging retentionist states not to extend the death penalty to new categories of offenses).

Heinonline -- 99 Am. J. Int'l L. 7712005
} 
death penalty usually give the retentionist argument short shrift, couching it in terms of vengeance that make no reference to terms and concepts that are cognizable under international law. ${ }^{197}$ To remedy that deficiency, we consider three approaches to evaluating the competing claims.

\section{The Rights-Based Approach}

The first option is a classic balancing test between individual rights and social welfare. In this particular instance, we would compare the absolute right to be free from execution with the social welfare need to pursue transitional justice. ${ }^{198}$ This approach replicates the traditional view of rights as trumps against utilitarian balancing. ${ }^{199}$ The retentionist can appeal to the utilitarian welfare of the community as a whole, and the role of executions within that program, but no amount of talk about utilitarian welfare will outweigh the trumping character of the right involved. ${ }^{200}$ However, the retentionist may very well respond to the attack by denying the right's universality. ${ }^{201}$

Although this structure of rights against social welfare is a classic framework, it is ultimately unhelpful because the abolitionist advances an absolute and universal right to be free from execution in all circumstances-which is precisely what the retentionist position denies. The retentionist will reject either the idea of a universal right to life or its application to criminals convicted of genocide. ${ }^{202}$ In both cases, the result is a stalemate.

One might respond by reconceiving the social welfare side as a question of rights as well. The retentionist could argue that the state has a group right to establish an autonomous legal system that protects individuals from the horrors of genocide. The theoretical rationale for positing the group right is that the state is a legal person with rights under international law. ${ }^{203}$ The state is a rational agent, capable of acting on the international stage and asserting its rights while also being held responsible for its actions before international adjudicatory bodies. ${ }^{204}$ The result now becomes a conflict not between rights and social welfare, but between two kinds of rights. This dilemma only heightens the sense of intractability.

One possible objection to this framework is metaphysical anxiety over the concept of group rights as such. ${ }^{205}$ Attributing a right to a group entity usually involves positing the existence

197 Cf. Berns, supra note 151, at 88 (arguing that a "moral community is not possible without anger and the moral indignation that accompanies it").

198 See, e.g., MANI, supra note 143, at 6-7 (describing the process of rectificatory justice).

199 See, e.g., Dworkin, supra note 184 , at 153.

${ }^{200}$ See SCHABAS, supra note 5, at 6-7.

${ }^{201}$ For example, the European Convention on Human Rights frames a human right to life but imposes several limitations on it, most notably that "[n]o one shall be deprived of his life intentionally save in the execution of a sentence of a court following his conviction of a crime for which this penalty is provided by law." ECHR, supra note 45, Art. 2. The Convention also lists the following exceptions to the right to life: self-defense, effecting a lawful arrest, and quelling riots and insurrections. Id.

202 See KERSHNAR, supra note 119, at 149-67 (defending harsh punishments, including the death penalty, on the basis of rights forfeiture).

${ }^{203}$ The idea of the state as a legal person has a long history in international law, going back at least as far as Vattel. EMmerich DE VATTEL, The LAw of Nations, bk. I, ch. I, \$12, at 3 (Joseph Chitty ed., Philadelphia, T. \& J. W. Johnson 1853) (1758). The notion also appears prominently in Kant's philosophy of international law. KANT, supra note 154 , at 114 .

${ }^{204}$ International instruments often use the language of moral personhood to describe international legal relations. See, e.g., Declaration on Principles of International Law Concerning Friendly Relations and Co-operation Among States in Accordance with the Charter of the United Nations, GA Res. 2625, UN GAOR, 25th Sess., Supp. No. 28, at 121, 124, UN Doc. A/8082 (1970) (states are juridically equal and must respect the personality of other states); OAS CHARTER, Apr. 30, 1948, Art. 9, 2 UST 2394, 119 UNTS 3 (equality of the state and its subsequent rights depend "upon the mere fact of its existence as a person under international law").

${ }^{205}$ For a discussion of the controversy, see generally Philip Pettit, Collective Persons and Powers, 8 LEGAL THEORY 443 (2002).

HeinOnline -- $99 \mathrm{Am}$. J. Int'l L. 7722005 
of a group agent, and this suggestion has met with scholarly controversy. ${ }^{206}$ Some consider the group agent to be a metaphysical fiction. ${ }^{207}$ Others have suggested that we can still talk about group rights without positing the existence of a group agent, or perhaps that our talk of group agents is metaphoric language meant to facilitate the attribution of rights. ${ }^{208}$

But we need not resolve this philosophical controversy here. It may be sufficient to note that the appeal to group rights does not fully encapsulate the intuitive appeal of the retentionist argument. No matter how the issue is analyzed, a rights-based paradigm does not faithfully recreate the retentionist legal argument, for two reasons. Either that argument will immediately be defeated because the social welfare will be trumped by the human right to life, or it will be stalemated by two kinds of mutually trumping rights: a group right to transitional justice and the individual right to life. Thus, even if we can overcome our jurisprudential anxieties and accept group rights, the result will not suffice to encapsulate the retentionist argument.

\section{A Consent-Based Approach}

The second approach to consider is consent based. Under this approach, the human right to life is applied only against a state that has voluntarily agreed to be bound by the legal norm. ${ }^{209}$ The abolitionist seeks to make retentionist states enforce the consequences of the rights that they have already consented to enforce, through various international instruments. ${ }^{210}$ Obviously, the retentionist denies having agreed to such a broad commitment. Although retentionist states are parties to the International Covenant on Civil and Political Rights, and are bound by its terms to protect the right to life, they are not parties to the Optional Protocol and have not agreed to forgo capital punishment as a result of their international obligations. ${ }^{211}$

The first objection to this approach notes that the abolitionist appeals to a nonderogable human right: the right to life. ${ }^{212}$ The abolitionist believes in a robust theory of rights and locates them within the framework of jus cogens. ${ }^{213}$ These international norms are allegedly so imperative that no state should be allowed to exempt itself by claiming persistent objector

\footnotetext{
206 See Ronald Dworkin, Liberal Community, 77 CAL. L. REV. 479, 493 (1989) (discussing example of the unified agency of an orchestra); Adeno Addis, Individualism, Communitarianism, and the Rights of Ethnic Minorities, 67 NOTRE DAME L. REV. 615 (1992) (arguing that ethnic rights can only be understood as the right of a group unit of agency). In fact, Addis argues that "it must be accepted that it is not metaphysical nonsense to talk about the rights of groups." Id. at 655; cf. PETER A. FRENCH, COLIECTIVE AND CORPORATE RESPONSIBILITY 35 (1984); Roger Scruton, Corporate Persons, 63 ARISTOTELEAN SOC'Y 239, 245-49 (Supp. 1989).

${ }^{207}$ See, e.g., Sanford A. Schane, The Comporation Is a Person: The Language of a Legal Fiction, 61 TUL. L. REV. 563, 563 (1987) (discussing the history of the concept of corporate personhood in U.S. law); $c f$. Kathryn L. Boyd, Collective Rights Adjudication in U.S. Courts: Enforcing Human Rights at the Corporate Level, 1999 BYU. L. RÈ. 1139, 1172 (1999).

${ }^{208}$ See, e.g., WILL KYMLICKA, MULTICULTURAL CITIZENSHIP 34-35 (1995) (discussing collective rights); Jeremy Waldron, Taking Group Rights Seriously, in LITIGATING RIGHTS: PERSPECTIVES FROM DOMESTIC AND INTERNATIONAL. LAW 203 (Grant Huscroft \& Paul Rishworth eds., 2002); Jeremy Waldron, Minority Cultures and the Cosmopolitan Alternative, 25 U. MICH. J.L. REFORM 751, 751 (1992) (discussing the rights of minority cultures without positing the existence of a group agent).

${ }^{209}$ For an example of the voluntarist approach, see KAROL. WOLFKE, THE CONCEPT OF CUSTOMARY INTERNATIONAL LAW (1993); of. Eduardo Moises Penalver, The Persistent Problem of Obligation in International Law, 36 STAN. J. INT'L L. 271, 276 (2000) (discussing the source of international law's obligatory character); Oscar Schachter, Towards a Theory of International Obligation, 8 VA. J. INT'L L. 311 (1968). Although the voluntarist theory was once dominant, its influence has receded as international lawyers have sought to apply human rights norms to recalcitrant states through customary international law and jus cogens. For a discussion of this transformation, see John A. Perkins, The Changing Foundations of International Law: From State Consent to State Responsibility, 15 B.U. INT'L L.J. 433, 437-39 (1997).

${ }^{210}$ See, e.g., ICCPR, supra note 24, Art. 6; ECHR, supra note 45, Art. 2; Charter of Fundamental Rights of the European Union, Dec. 7, 2000, Art. 2, 2000 O.J. (C 364) 1, 40 ILM 266 (2001); American Convention on Human Rights, supra note 44 , Art. 4.

211 On the Optional Protocol, see supra note 25.

${ }^{212}$ See ScHABAS, supra note 5, at 19 (discussing the emergence of a jus cogens norm).

${ }^{213} I d$.

Heinonline -- $99 \mathrm{Am}$. J. Int'l L. 7732005
} 
status. ${ }^{214}$ Consequently, the notion of consent is a nonstarter. Some human rights obligations should be enforced when the states concerned have not consented to their application. This is an appealing argument for the abolitionist, who claims that the retentionist states should be precluded from using capital punishment against genocide because it violates a jus cogens norm.

This article cannot offer a complete analysis of the nonderogability argument and its applicability to the right to life. Perhaps it is sufficient to note that jus cogens remains one of the most controversial areas of international legal scholarship, for the very reason that its content is so difficult to fix. ${ }^{215}$ While some scholars are inclined to include human rights norms in the jus cogens framework, ${ }^{216}$ precisely to achieve universal compliance, other legal scholars offer a more modest reading of its scope and content. ${ }^{217}$ According to this view, jus cogens is limited to universal notions such as the principle of legality and nulla poene sine lege, but does.not include specific rights that are respected in some societies but not in others. ${ }^{218}$

The result of this skepticism is yet another stalemate. The retentionist appeals to the notion of consent and the fact that retentionist states have not consented to withdrawing capital punishment from their penal system. ${ }^{219}$ The abolitionist denies the need for consent and appeals to the nonderogability of the human right to life. ${ }^{220}$ The retentionist responds by noting the limited character of jus cogens and its inability to resolve by fiat the question of capital punishment. ${ }^{221}$ There is little flexibility for settling the conflict and no framework within which to express, under international law, the special reasons a retentionist might have for retaining the death penalty.

Why have both the consent-based approach and the rights-based approach failed to resolve the tension? Neither paradigm is sufficient for exploring the true intuitive appeal of a state's need to pursue transitional justice in the wake of genocide. What is needed is a paradigm that expresses, in legal terms, the legitimate desires of the retentionist state faced with repairing its culture after a genocidal campaign. While this approach may not necessarily trump all other considerations, it should be a central legal interest in our analysis. ${ }^{222}$ We next look to the United Nations Charter and its most fundamental principles to find a solution.

\section{International Peace and Security as a Charter Norm}

International peace and security. The goal of maintaining and restoring international peace and security is a high priority under the Charter, and arguably it is the highest goal of international law. ${ }^{223}$ This goal is important not just for evaluating Security Council authorization J. Paust, The Reality ofJus Cogens, 7 CONN. J. INT'L L. 81 (1991). See also Vienna Convention on the Law of Treaties, opened for signature May 23, 1969, Art. 53, 1155 UNTS 331 (defining jus cogens as "peremptory norms of general international law"); RESTATEMENT, supra note $23, \$ 702$ (listing nonderogable human rights obligations).

${ }^{216}$ See, e.g., RESTATEMENT, supra note $23, \$ 702 \mathrm{cmt}$. $n$.

${ }^{217}$ SCHACHTER, supra note 39, at 70-76; see also LOUIS HENKIN, THE AGE OF RIGHTS (1990).

${ }^{218}$ See, e.g., HENKIN, supra note 34, at 38; THEODOR MERON, HuMAN RigHTS AND HuMANITARIAN NORMS As CusTOMARY LAW (1989).

${ }^{219}$ See, e.g., supra notes $126-33$ and corresponding text.

${ }^{220}$ See Chairman's Working Paper, supra note 83 (discussing international objections to the death penalty).

${ }^{221}$ See RESTATEMENT, supra note $23, \$ 702 \mathrm{cmt}$. $f$ (describing capital punishment as an open question still permissible under customary international law).

${ }^{222}$ Although the preferred conceptual scheme will be developed in the next section, these are not mutually exclusive strategies. Elements from each one might be combined to ground a convincing analysis of the problem.

${ }^{223}$ UN CHARTER, pmbl. ("to unite our strength to maintain international peace and security"), Art. 1 (purpose of United Nations is to maintain international peace and security), Art. 39 (Security Council duty to "maintain or restore international peace and security"), Art. 42 (authorizing military actions "to maintain or restore international peace and security"), Art. 43 (duty of member states to offer military support for actions necessary to maintain or restore international peace and security), Art. 52 (Charter is consistent with regional arrangements for maintaining

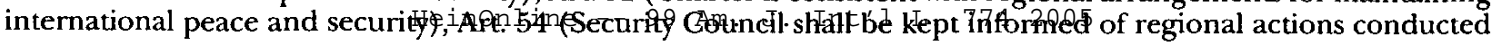


of military intervention, ${ }^{224}$ but because it pervades international law. It supports the very foundation of the international legal order and as such must be considered a background norm, aiding in the interpretation of international legal standards and providing context for arguments about customary international law. Therefore, the concept of international peace and security cannot be swept aside and replaced with a rights-only conception of international legal discourse. ${ }^{225}$ Any rights-based discussion of international law must be read in tandem with such foundational principles of international law as the duty to preserve international peace and security. ${ }^{226}$ Though rights must not always give way to the needs of peace and security, international peace and security must not always be subordinated to human rights discourse. The two concepts must be read together.

The role of reconciliation in peace and security. The period after genocide is crucial for international peace and security. ${ }^{227}$ If the victims of genocide have managed to regroup after the attack, or indeed have stopped the attack by gaining control of the country, they may respond by engaging in reprisal killings. ${ }^{228}$ But the reprisals may be more than isolated instances in villages controlled by that ethnic group. The reprisals may take the form of renewed regional violence that implicates other states, for example by spreading into their territory or by giving rise to pressure for outside intervention. ${ }^{229}$ National reconciliation may therefore be more than simply a national concern. ${ }^{230}$ Ethnic reconciliation in the face of genocide may be a matter of international concern. Failure to repair the ethnic wounds of genocide may result in a continuing threat to international peace and security. ${ }^{231}$ Although the wounds of genocide can never be completely healed, they might be alleviated enough to stop the spread of ethnic violence across an entire region. Hence, a war that was once of purely internal consequence may implicate international considerations.

When the Security Council authorized the ad hoc tribunals, it did so under its Chapter VII powers. ${ }^{232}$ Furthermore, when the legal authority of the tribunals was questioned in the Tadic

to maintain international peace and security); see, e.g., Mariano-Florentino Cuellar, Reflections on Sovereignty and Collective Security, 40 STAN. J. INT'L L. 211, 214 (2004) (evaluating international law's success in achieving international peace and security).

${ }^{224}$ Arguments about the use of force make frequent reference to Security Council authority under the Charter. See, e.g., Oscar Schachter, In Defense of International Rules on the Use of Force, 53 U. CHI. L. REV. 113,128 (1986) ("[T]he failure of self-help and international institutions to provide adequate remedies for breaches of legal rights does not impugn the efficacy of the Charter's collective machinery. That machinery does not purport to safeguard legal rights: it was meant to ensure peace and security."); see also Oscar Schachter, International Law: The Right of States to Use Armed Force, 82 MICH. L. REV. 1620, 1620-22 (1984) [hereinafter Schachter, Right of States] (discussing the legal authority of the Security Council).

${ }^{225}$ See Schachter, Right of States, supra note 224, at 128 (noting that the international legal order was not designed to vindicate individual legal rights, but to maintain international peace).

${ }^{226} I d$. (noting that "[o]ptional judicial machinery" is available to hear such disputes).

${ }^{227}$ See, e.g., MANI, supra note 143, at 53 (asserting that reestablishing rule of law is necessary for achieving international peace in postconflict societies); Chamblee, supra note 18 (noting that Hussein's trial will promote reconciliation). For a general discussion of the role of the rule of law in international relations, see HANS KELSEN, PEACE THROUGH LAW (1944).

${ }^{228}$ Payam Akhavan, Justice and Reconciliation in the Great Lakes Region of Africa: The Contribution of the International Criminal Tribunal for Rwanda, 7 DUKE J. COMP. \& INT'L L. 325, 338-39 (1997).

${ }^{229}$ Id. at 339; see also Payam Akhavan, Justice in The Hague, Peace in the Former Yugoslavia? A Commentary on the United Nations War Crimes Tribunal, 20 HuM. RTS. Q. 737, 741 (1998).

${ }^{230}$ See MANI, supra note 143, at 4 (discussing the connection between restoring justice and international peace and security); Akhavan, supra note 228, at 339 (noting that the "symbolic effect of prosecuting even a limited number of such leaders before an international jurisdiction would have considerable impact on national reconciliation as well as deterrence of such crimes in the future"); Antonio Cassese, Reflections on International Criminal Justice, 61 MOD. L. REV. 1, 10 (1998) (concluding that the lack of international tribunals will allow hatred and revenge to threaten international peace and security).

231 The ethnic divisions in Iraq cut across state lines and extend into Iran, Turkey, and other neighboring states.

${ }^{232}$ Security Council members explicitly stated the goal of restoring international peace and security, as well as national reconciliation. UN Doc. S/PV.3453, supra note 1, at 2-3.

HeinOnline -- $99 \mathrm{Am}$. J. Int'l L. 7752005 
case, the ICTY explicitly endorsed the view that its jurisdiction was authorized under the Security Council's Chapter VII powers. ${ }^{233}$

Objections. One might object that the framework of international peace and security proves too much. In many cases, the goals of international peace and security were met by national reconciliation programs that did not institute the death penalty ${ }^{234}$ For example, South Africa responded to the crime of apartheid by instituting the Truth and Reconciliation Commission, which did not have the authority to impose the death penalty, even though many perpetrators who came before the commission confessed to serious transgressions during the apartheid regime. ${ }^{235}$ If South Africa can come to terms with its internal difficulties without resorting to the death penalty, while simultaneously protecting international peace and security, then presumably the appeal to international peace and security is superfluous.

There are several responses to this objection. First, South Africa decided for itself to establish the truth commission; this decision was not imposed on it by the international community. ${ }^{236}$ The route it chose was based on forgiveness and reconciliation, as well as the conscious decision that the damage to its society could not be repaired without a complete accounting of the truth about apartheid. ${ }^{237}$ South African officials felt that such an accounting would never be rendered unless forgiveness was available for those who confessed. ${ }^{238}$ Otherwise, those complicit in the crimes of apartheid would have no incentive to divulge the truth.$^{239}$ These calculations are country specific and would not necessarily apply to the culture of other countries, such as Rwanda. ${ }^{240}$ For South Africans, it was important to decide for themselves how their reconciliation would be achieved. It was their choice.

Second, the South African situation is difficult to compare with cases of full-scale genocide, as occurred in Rwanda, Yugoslavia, and Iraq. ${ }^{241}$ Apartheid certainly implicated international interests, but it did not represent the same level of danger to international peace and security as a genocidal attack that threatens to engulf an entire region in ethnic war. South Africa did not face the kind of ethnic conflict between, for example, Sunnis, Shiites, and Kurds that threatens to destabilize Iraq and its neighbors.

Third, and more important, our goal is not to prove that the retentionist policy is justified in cases of genocide. Rather, it is to locate and select the best possible legal framework for formulating the arguments of a retentionist state faced with repairing the damage of genocide. The duty to preserve international peace and security means that the retentionist state can appeal to the most basic principles of international law when defending the legality of its practices. The legal issue cannot simply be framed as respect for human rights against flagrant disregard for them. Nor can the issue be framed as respect for Western human rights on the one hand, versus respect for cultural diversity on the other hand. Both of these dichotomies fail to place the retentionist argument on the best possible ground, because in both the first half of the dilemma is explicitly legal, while the second half is vague and extralegal. If we are to remain intellectually rigorous, we must evaluate the retentionist argument on the best possible legal grounds. It should stand or fall on that basis.

\footnotetext{
${ }^{233}$ Prosecutor v. Tadić, Appeal on Jurisdiction, No. IT-94-1-AR72 (Oct. 2, 1995).

234 See MANI, supra note 143, at 101-02 (evaluating trade-offs associated with truth commissions and noting that "the popularity and ubiquity of TCs are a cause for concern").

${ }^{235}$ For a general discussion of the commission, see Paul van Zyl, Dilemmas of Transitional Justice: The Case of South Africa's Truth and Reconciliation Commission, 52 J. INT'L AFF. 647 (1999). See also DESMOND TUTU, No FUTURE WITHOUT FORGIVENESS (1999).

${ }^{236}$ TuTu, supra note 235; van Zyl, supra note 235.

${ }^{237}$ TUTU, supra note 235.

${ }^{238} I d$.

${ }^{299}$ Van Zyl, supra note 235.

${ }^{240}$ Cassese, supra note 230, at 3 (noting that although the truth-and-reconciliation model was appropriate for South Africa, it would not have worked in Rwanda or Yugoslavia).

${ }^{241}$ Id. at 4 (arguing that perpetrators continued to "preach the gospel of ethnic separation" in Yugoslavia and Rwanda). 


\section{CONCLUSION}

A dictum of criminal justice states that "beautiful theories have a way of turning into ugly practices." 242 There is certainly that danger here. Subtle legal arguments always run the risk of being cited for the wrong proposition or used to justify unscrupulous practices. That risk, while always present, is most acute when the subject is so morally charged.

This article has questioned the conventional wisdom that the death penalty violates the emerging norm of customary international law on the death penalty in all circumstances, including genocide. It may very well be that abolishing the death penalty represents the continued civilization of human society. Nothing in this article questions that trend. Its sole aim is to suggest that customary international law forbids neither a retentionist state nor a future international tribunal from resorting to capital punishment for crimes of genocide. It would therefore be wrong to interpret this analysis as an argument against abolishing the death penalty in the United States or internationally, or as an argument for imposing the death penalty for crimes of genocide. Although mercy might counsel against resorting to the death penalty, we have attempted to demonstrate that the question extends beyond abstract principles of human rights and encompasses complex questions of international peace and security that rest at the very foundation of international law.

242 The maxim is attributed to Thorsten Sellin, quoted in BRATTHWAITE \& PETTIT, supra note 149, at 153-54 (quoting FRANCIS T. CULLEN \& KAREN E. GILBERT, REAFFIRMING REHABILITATION 151 (1982)). 